\title{
Farklı Sokak Kanyonlarında Rüzgârın Hava Kirliliği Dağılımı Üzerindeki Etkisi: Erzurum Örneği
}

\section{The Effect on Air Pollution Distribution of Wind in Different Street Canyons: The Case of Erzurum}

\author{
Elif Nur Sarı, ${ }^{1}$ (1) Sevgi Yılmaz ${ }^{2}$
}

${ }^{1}$ İstanbul Üniversitesi-Cerrahpaşa Orman Fakültesi, Peyzaj Mimarlığı Bölümü, İstanbul

${ }^{2}$ Atatürk Üniversitesi Fen Bilimleri Enstitüsü, Peyzaj Mimarlığı Anabilim Dalı, Erzurum

\section{ÖZ}

Kentlerde nüfusunun hızla artması, çevre sorunlarının çeşitlenmesine ve yeni boyut kazanmasına yol açmaktadır. Özellikle kış aylarında artış gösteren hava kirliliği kentlerde yaşanabilirlik açısından dış mekân konforunu olumsuz yönde etkilemektedir. Bu çalışmanın amacı, farklı özelliklerdeki sokak kanyonlarında rüzgârın hareketi, ağaçların varlığı ve bunların hava kirliliğinin dağılımına etkisini analiz ederek, sokak ölçeğinde yayalar için daha konforlu tasarım kriterlerini belirlemektir. 2018 yılı hava kirliliği verilerinin analizinde ve haritalamasında ArcGIS 10.3 Spatial Analysis Modülündeki Interpolation yöntemi kullanılarak, Erzurum kenti için hava kirliliğinin mekânsal analizi haritalandırılmıştır. Oluşturulan hava kirliliği haritasında, kirliliğin yoğun ve az yoğun olduğu mevcut mekânlardan, ağaçlı ve ağaçsız olmak üzere dört farklı sokak kanyonu belirlenmiştir. Belirlenen sokak kanyonlarının analizinde Sayısal Akışkanlar Dinamiği (CFD) ANYSY 16.0 bilgisayar programı kullanılmıştır. Sokak analizleri, rüzgâr akış hızı, bina çatısı, ağaçlar ve yaya seviyesine göre karşılaştırılmış, yaya seviyesinde daha düşük olduğu belirlenmiştir. Hava kirliliğinin az olduğu sokaklarda; ağaçsız sokakta \%23, ağaçlı sokakta \%25 rüzgâr hızında düşüş olduğu hesaplanmıştır. Hava kirliliğinin yüksek olduğu sokaklarda; ağaçsız sokak \%29 ve ağaçlı sokak da \%57 oranında rüzgâr hızında azalma olduğu saptanmıştır. Sonuç olarak, sokak kanyonları özelliklerine göre rüzgârın yönünü ve hızını etkileyerek, hava kirliliğinin dağılımında önemli rol aldığı belirlenmiştir. Sokağın

\section{ABSTRACT}

The rapid increase in the population of cities leads to the diversification and new dimensions of environmental problems. Air pollution, which increases especially in winter, negatively affects outdoor comfort in terms of liveability in cities. The aim of this study is to analyze the movement of wind, the presence of trees and their effect on the distribution of air pollution in street canyons with different characteristics and to determine more comfortable design criteria for pedestrians at street scale. Air pollution data for 2018 were analyzed using the Interpolation method in ArcGIS 10.3 Spatial Analysis Module. Erzurum air pollution spatial analysis map was produced. According to the spatial analysis map of air pollution, four different street canyons, with and without trees, were randomly selected from the streets where the pollution is intense and less intense. Computational Fluid Dynamics (CFD) ANYSY 16.0 software program was used in the analysis of the determined street canyons. Street analysis was compared according to wind flow velocity, building roof, trees and pedestrian level, and it was found to be lower at pedestrian level. In the streets with less air pollution, it has been calculated that there is $23 \%$ decrease in wind speed in treeless streets and $25 \%$ in tree-lined streets. In the streets with high air pollution; It was determined that there was a decrease in wind speed by $29 \%$ in the treeless street and $57 \%$ in the tree-lined street. As a result, it has been determined that street canyons play an important role in the distribution of air pollution by affecting the direction and speed of the wind according to their characteristics. 
hakim rüzgâr yönüne paralel olması ve rüzgârı engelsiz olarak alması hava kirliliğinin dağılmasında iyileştirici bir etken olarak görülmüştür. Dar sokak kanyonlarında ise ağaçların kullanılmasının rüzgâr hızını engellediği saptanmıştır. Ayrıca, binalar arası mesafesi az olan ve dar kanyon özelliği gösteren sokaklarda ise hava kirliliğinin daha fazla yoğunlaştığı belirlenmiştir. Geniş sokak kanyonlarının ağaçlandırılmasında rüzgârın hızını kesmeyen, yüksekten dallanan ve geçirgen dokuya sahip olan ağaç türlerinin tercih edilmesi gerektiği vurgulanmıştır. Alanın doğal özellikleri dikkate alınarak tasarlanacak sokakların yaya dostu ve daha yaşanabilir mekânlar olacağı vurgulanmıştır.

Anahtar sözcükler: Ağaçlar; Erzurum; hava kirliliği; rüzgâr; Sayısal Akışkanlar Dinamiği (CFD); sokak kanyonu.

\section{Giriş}

Günümüzde yapılan hesaplamalara göre, Dünya nüfusunun \%55'i kentlerde yaşarken bu oranın 2050'de \%68'e ulaşması beklenmektedir (UN, 20I8). Bu artışa cevap verebilmek için doğa ile iç içe barışık yaşamayı unutan insanoğlu, kentsel mekânlarda tasarımı birim alana en fazla konut sığdırmak şeklinde değiştirmiştir. Kentlerde yaşanan hızlı yapılaşmada doğal verilerin ve planlama kriterlerinin göz ardı edilmesi çeşitli çevre sorunlarını da beraberinde getirmektedir. Bunlar arasında hava kirliliği tüm canlıların sağlığını olumsuz yönde etkileyen önemli bir çevre sorunu olarak görülmektedir. Hava kirliliğinin insan sağlığı üzerindeki etkisini azaltmak için Dünya Sağıı Örgütü (WHO), partikül madde (PM), nitrojen dioksit $\left(\mathrm{NO}_{2}\right)$, ozon $\left(\mathrm{O}_{3}\right)$ ve kükürt dioksit $\left(\mathrm{SO}_{2}\right)$ gibi yaygın hava kirleticiler için hava kalitesi kılavuzlarını hazırlamıştır (WHO, 2005). Hava kirliliği normal şartlarda havada bulunan oksijen, azot ve diğer maddeler dışında farklı gaz partiküllerinin havaya karışması veya mevcut gazların oranlarının değişmesi ile oluşmaktadır (Partigöç ve Çubukçu 2017). Hava kirliliği çalışmalarında, artan fosil yakıtların tüketimi, araç kaynaklı kirlilik, topoğrafik yapı, sokak kanyonu ve konut dokusu ile ilişkisi üzerinde durulduğu belirlenmiştir (Clark vd., 20II; Lu ve Liu, 2016; Schindler ve Caruso, 2014; Zhou vd., 2016).

Bu araştırmada, kentsel mekânlarda hava kirliliğini etkilediği görülen sokak kanyonları ve rüzgâr hareketliliği incelenmiştir. Binaların yüksekliğinin yol genişliğine oranına sokak kanyonu denmektedir (Ali-Toudert ve Mayer, 2006; Canan, 2017). Yüksekliğin genişliğe oranı (Y/G) ile hesaplanan sokak kanyonu dar ve geniş olarak nitelendirilmektedir (Oke, 1988; Shi vd., 2018; Yilmaz vd., 2018). Yapılan bir çalışmada ideal termal konfor için en uygun sokak kanyonunun Y/G: 0.5-I.0 arasında değerlere sahip olması gerektiği belirtilmiştir (Shishegar, 2013; Bendida vd., 2019). Farklı modeller arasında yapılan simülasyon çalışmaları sokak kanyonunda kirleticilerin sokağın uzunluğu, genişliği, konut tipolojisi, bina yoğunluğu, bina yüksekliği, bina yüzey kaplamaları gibi bir çok faktöre göre karakterize edildiğini de göstermektedir (Hunter ve Wales, 1992; Taseiko vd., 2009; Ma vd., 2020).
The fact that the street is parallel to the prevailing wind direction and that it receives the wind unimpeded has been seen as a healing factor in the dispersion of air pollution. It has been determined that the use of trees in narrow street canyons reduces wind speed. In addition, it has been determined that the air pollution is more intense in the streets with narrow canyon characteristics with less distance between buildings. It was emphasized that tree species that do not slow down the wind speed, for example species with high branches and a permeable texture should be preferred in the afforestation of wide street canyons. It was emphasized that if the streets are designed considering the natural characteristics of the area, they will be pedestrian friendly and more liveable places.

Keywords: Trees; Erzurum; air pollution; wind; Computational Fluid Dynamics (CFD); street canyon.
Sokak kanyonunu etkileyen önemli diğer parametre de sokak uzunluğudur. Sokağın uzunluğu, yerleşim açısı ve rüzgâr hareketliliği mikroklimatik koşulları etkilemektedir (Ali-Toudert ve Mayer, 2006; Hang vd. 2009; Qaid ve Ossen 20I5; Mutlu vd., 20/8). Hesaplamalı Akışkanlar Dinamiği (CFD) ile yapılan bir rüzgâr analizinde, yüksek katlı binaların sokak kanyonlarında havalandırmayı engellediği ve bu alanda daha yüksek kirletici yoğunluğu saptanmıştır (Fu vd., 2017; Sari ve Yilmaz,2019). Binalar arası mesafenin azalması girdap oluşumunu tetiklemektedir (Hunter ve Wales, 1992). Binaların birbirine çok yakın olması ile oluşan girdap etkisine, bir de I-2 m/s'den daha düşük rüzgâr hızı eklendiğinde hava kirliliği bloke olarak kalmaktadır (DePaul ve Sheih, 1986; Ketterer ve Matzarakis, 2016). Rüzgâr hızını etkileyen diğer faktörler, sokaktaki ağaçlar, çok katlı yapılar, çatı seviyeleri, eğimli bina çatıları, balkonlar, bina yüzeyindeki pürüzlülük olarak gösterilmektedir (Eskridge ve Rao, 1986; Theurer, 1999; Shishegar, 20l3; Bendida vd., 20l9). Bina çatılarındaki yükseklik-alçaklıkla oluşan küçük değişimler önemli ölçüde rüzgâr akışının dağılımını değiştirebilmektedir (Balogun vd., 20।0; Klein vd., 2007; Hang vd., 2009). Hava kirliliği akışı, sokak boyunca kirlilik yoğunluk seviyeleri rüzgâr yönünün değişmesi ile belirgin şekilde değişmektedir (Neofytou vd., 2006).

Binaların çatıları sokak kanyonuna paralel olarak konumlandığında rüzgârın etkisi ile kanyon içerisindeki kirli hava daha kolay dağılmaktadır. Rüzgâr hızı ve rüzgâr yönü kanyondaki hava akışı üzerinde önemli bir etkiye sahiptir (Ali-Toudert ve Mayer, 2006; Zhang vd., 20I5). Uzun sokak koşullarında sokak çatısı boyunca türbülanslı taşımanın oldukça önemli olduğu saptanmıştır (Hang vd., 2009). Havalandırmanın etkisi ise sokak uzunluğu arttıkça azalmaktadır (Theurer, 1999). Rüzgârın yönü ve sokak yönü arasındaki ilişkiye bağlı olarak hava kirliliği konsantrasyonlarında ve dış mekân termal konforunda artış ve azalışlar mümkün olmaktadır (Schatzmann vd., 2000; Yilmaz vd., 2018). Bir sokak kanyonunu daha iyi havalandırmak için kanyonun daha aşağıda olan üst çatılara, yani kat yüksekliğinin azaltılmasına ihtiyaç olduğu belirtilmiştir. Ancak bu tek başına yeterli olmayıp rüzgâr yönünün de dikkate alınması gerektiği belirtilmiştir (Nosek vd., 2018). 
Ağaçlar hava kalitesinin iyileştirilmesinde önemli bir dengeleyici ve düzenleyici unsur olarak incelenmektedir (Pugh vd., 20I2; Berardi vd., 20I4). Ağaçlar ve çalılar güneş radyasyonunu ve gün boyunca çevrenin yüzey sıcaklığını azaltıp geceleri ISı alışverişini önleyerek binalardan ısı akışını önlemektedirler (Akbari vd., 200I; Aksu vd., 2020). Yapılan bir çalışmada ağaçların yıllık 88 ton kirliliğin ortadan kaldırılmasında önemli rol oynadığı saptanmıştır (Wania vd., 20I2). Yapılan bir araştırmada, ağaçlar ve çim yüzeyin kıyaslaması, rüzgâr akışı ile yapılmış ve CFD modeliyle analizle edilmiştir. Hava kirliliğinde düşüş, ağaçlarda \%2.8'lik azalma ve çim zemin kaplı yüzeylerde \%0.6'lık oranında azalma meydana geldiği saptanmıştır (Jeanjean vd., 2016). Kentte yeşil dokunun var olması hava kalitesine ve kentsel sürdürülebilirliğe önemli ölçüde katkı sunmaktadır. Ancak ağaçların kirleticileri azaltmada doğrudan etkisinden ziyade sokak kanyonunun ve rüzgâr karakteristiklerinin daha önemli olduğunu vurgulayan çalışmalar dikkat çekmektedir (Shashua-Bar ve Hoffman, 2000). Ağaçların niceliksel olarak hava kirliliğini azaltma etkisinden ziyade kirliliğin mahalle ölçeğinde tartışılması gerektiği vurgulanmıştır (Balczó vd., 2009; Buccolieri vd., 20 I0; Salim vd., 20 I I; Vos vd., 2013; Wania vd., 2012; Akkar ve Belge, 2017). Mahalle ölçeğinde yapılan bazı çalışmalarda ağaçların kirletici yoğunluğunda artışa neden olduğu saptanmıştır (Gallagher vd., 2015; Gromke ve Blocken, 2015; Li vd., 2019). Özellikle bazı sokaklarda rüzgâr hareketi ve girdaplar hem sokak karakteristikleri hem de bitki örtüsü tarafından etkilenmektedir. Sokak kanyonundaki ağaçların rüzgâr akışını engelleme veya yönünü değiştirme etkisine sahip olduğu saptanmıştır (Shi vd., 2018). Ayrıca geniş taçlı ağaçlar kanyonun büyük bir kısmını işgal ederek, havayı bloke etme etkisine neden olmaktadır (Buccolieri vd., 2010; Salim vd., 20 I I; Gromke ve Blocken, 20I5). Yapılan araştırmalarda, hava kirliliğinin yoğun olduğu dar sokaklarda, yoğun-kompakt yapılı ağaçlar yerine geçirgen yapıya sahip yüksek boylu ağaçlar ile çalı formunun kullanılmasının gerekliliği vurgulanmıştır (Vos vd., 20I3; Gallagher vd., 20I5; Janhäll, 20I5). Hava kirliliğinin aynı zamanda kentin mikro kliması ve kentin formuyla da ilişkili olduğu görülmektedir. Ekolojik tasarımlarda kent formuyla ilgili, çevre-mekan-yapılaşma ilişkisi kapsamında, enerji koruma, kirlilik azaltımı, geri-dönüştürme projeleri ile birlikte ele alınması gerektiği vurgulanmıştır. Daha konforlu bir yaşam için kentte ekolojik tasarım yaklaşımlarının geliştirilmesi üzerinde durulmuştur (Gültekin, 2005).

Erzurum kentinde hava kirliliği ve kirliliğin etkileri üzerinde çaışmalar yapılmıştır. Kentte mevcut hava kirliliği ölçüm istasyonları verileri kullanılarak analizler yapılmış ve $\mathrm{SO}_{2}$ ile $\mathrm{PM}_{10}$ üzerinde durulmuştur. Hava kirliliğinin en yüksek değeri Erzurum kent merkezinde Yakutiye çevresinde olduğunu, en düşük değeri ise Atatürk Üniversitesi yerleşkesinin sahip olduğunu belirtmişlerdir (Kopar ve Zengin, 2009). Kentte hava kirliliğine karşı halkın duyarlılığını belirlemek için 300 kişi ile yapılan anket çalışmasında, katılımcıların \%66'sı hava kirliliğinin en önemli çevre soru- nunun olduğunu ifade ederken, \%94'ü ise kirliliğin sağlıklarını etkilendiklerini belirtmişlerdir (Yılmaz ve Sezen, 2004). Erzurum kenti için 20I2-2017 yılları arasındaki beş yıl $\mathrm{SO}_{2}$ ve $\mathrm{PM}_{10}$ değerleri açısından analiz edilmiş ve değerlerin hala istenilen seviyelerde olmadığını belirlemişlerdir (Koşan vd., 20।8). Başka bir çalışmada ise, Erzurum'un soğuk kentler arasında yer aldığı belirtilerek, iklime duyarlı kentsel tasarım yaklaşımları üzerinde durulmuştur (Dursun ve Yavaş, 20I7). Yavaş ve Yılmaz'da (2020) Erzurum'da kentsel yerleşim yerleri üzerinde analizler yaparak, dış mekân termal konforunu etkileyen faktörler arasında rüzgârın önemli rol aldığını belirlemişlerdir.

Köppen ve Geiger iklim gruplarına göre, Erzurum soğuk iklim sınıfında yer almaktadır (Öztürk vd., 2017). Araştırma alanı olarak seçilen Erzurum kentinde, kömür tüketiminin yanı sıra soğuk iklimin hakim olması nedeni ile uzun yıllardır hava kirliliği problemi yaşanmaktadır. 21 Ocak 2019'da Erzurum Valisi TV kanalında (CNN) hava kirliliğinin ciddi bir sorun olduğunu ve kent için acilen önlem alınması gerektiğini vurgulamıştır. Özellikle kış aylarında ısınma amaçlı kullanılan yakıtlar bu kirliliği artırmaktadır. Ayrıca kentin etrafının yüksek dağlarla çevrili olması, rüzgâr hızının düşüklüğü gibi faktörler kirliliğin dağılmasını da engellemektedir.

Bu çalışmada amaç, farklı özelliklerdeki sokak kanyonlarında hava kirliliği, ağaçlar ve rüzgârın dağılımını analiz ederek, sokak ölçeğinde yayalar için daha konforlu sokak tasarım kriterlerini belirlemektir. Erzurum kentinde kış aylarında hava kirliliğinin yoğun ve az yoğun olduğu bölgelerde, analiz yapmak için 4 farklı tipte sokak seçilmiştir. Hazırlanan kirlilik haritası üzerinde, kirliliğin yoğun ve az yoğun olduğu bu alanlarda hem ağaçlı hem ağaçsız sokaklar seçilerek bitkilerin etkisi de analiz edilmiştir. Kentsel mekânlarda yaşam ortamlarının hava kalitesinin iyileştirilmesi önerileri üzerinde durulmuştur. Çünkü bu durum insanların kış aylarında dışarıda zaman geçirmelerini zorlaştırmaktadır. Bu çalışmadan çıkan sonuçların kentte belirlenen 20'ye yakın kentsel dönüşüm alanının fiziki plan kararlarına aktarılması ve yerleşim alanlarında kentsel tasarım senaryoları için bir envanter niteliği taşıması öngörülmektedir.

\section{Materyal ve Yöntem}

Erzurum kenti yerleşim alanı ortalama olarak 1860-2050 m yükseklikte olup, Türkiye'nin KuzeyDoğu'sunda yer almaktadır. 20 I 2 yılında büyükşehir statüsüne sahip olan kentte nüfus 2017 sayımlarına göre 760476 kişidir (TÜiK 2017). 19. yy’dan günümüze kadar önemli planlama deneyimleri geçiren Erzurum kentinde (1939 Lambert Planı; 1966 Zeki Yapar Planı; 198I Alim Çapuroğlu Planı; 1990 Zühtü Can Limited şirketi) 2005 yılından sonra yerleşim alanı önerisi ovaya doğru yönlendirilmiştir (EBB Araştırma Raporu 2015). Erzurum'un konut dokusunu gecekondu tipi, müstakil tip, site tipi ve apartman tipi yapılaşmalar oluşturmaktadır. Etrafı yüksek dağlarla çevrili, çanak şeklinde 


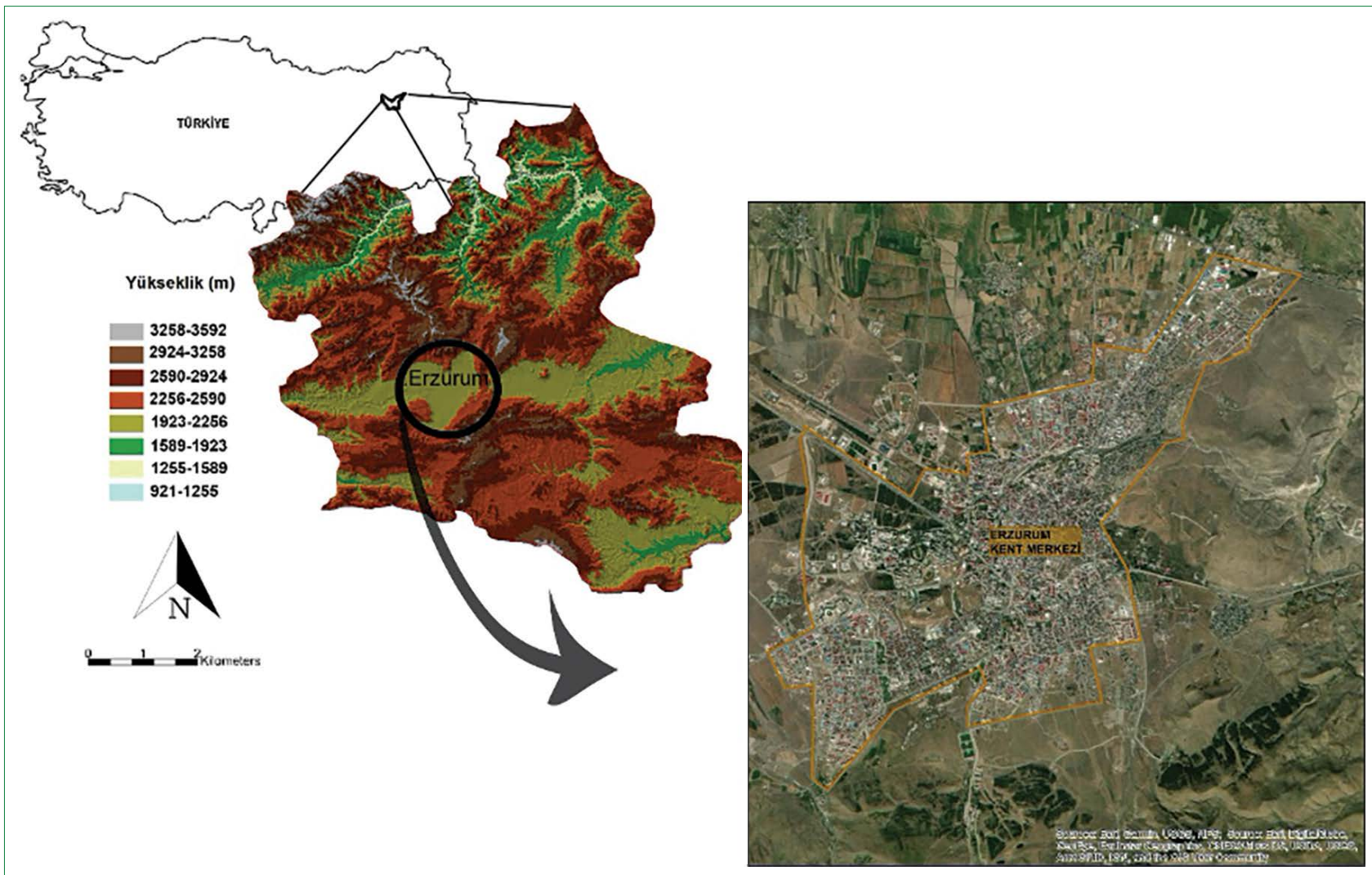

Şekil I. Erzurum Kenti topoğrafik durumu ve çalışma alanının konumu (Google Earth).

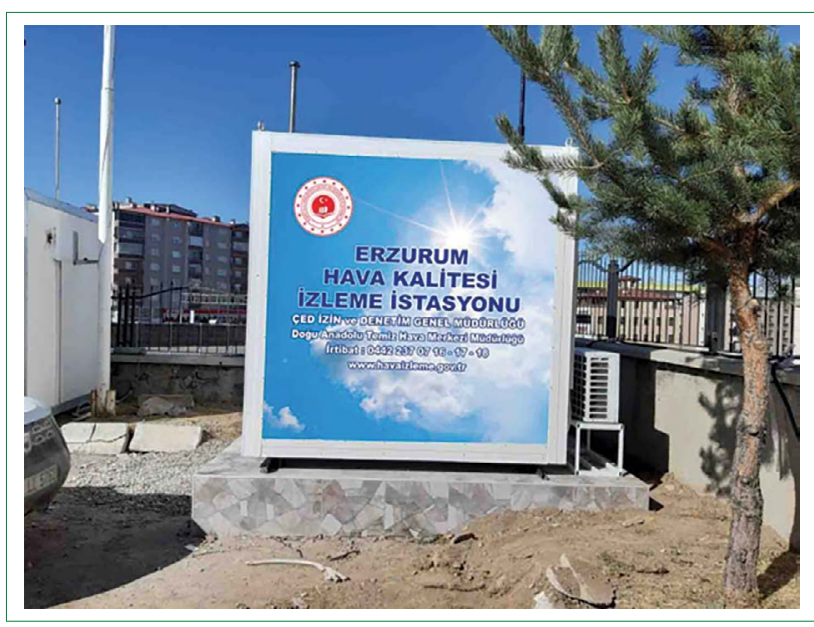

Şekil 2. Erzurum'da Hava kirliliğinin ölçüldüğü istasyonlardan birisi (ÇŞB, 20|8).

bir coğrafi alana sahiptir. Erzurum'un yerleşim alanının etrafının yüksek dağlarla çevrelendiğini gösteren topoğrafik durumu ve çalışma alanııın konum haritası Şekil I'de verilmiştir.

\section{I. Erzurum Kenti Kirlilik Haritasının Hazırlanması}

Çevre ve Şehircilik Bakanlığı'nın Erzurum kentinde kurduğu istasyonlar ile hava kirliliği verileri ölçülmektedir (URL-I). Bu siteden 2018 yılına ait hava kirliliği değerleri $\mathrm{CO}, \mathrm{PM}_{10}, \mathrm{SO}_{2}$ ve
$\mathrm{NO}_{2}$ alınmıştır (ÇŞB, 20I8). Erzurum kentinin genelinde beş farklı istasyonda ölçümler düzenli olarak yapılmakta ve web sayfasından veriler paylaşılmaktadır (Şekil 2). Bu verilerin analizinde ve haritalamasında "ArcGIS 10.3 Spatial Analyst Modülündeki Interpolation" altındaki "Inverse Distance Weighted (IDW)" komutu kullanılarak hazırlanmıştır.

\subsection{Analiz Edilen Sokaklara Ait Özellikler}

Elde edilen hava kirliliği haritaları üzerinde (Sarı, 2019), kirliliğin yoğun ve az yoğun olduğu noktalar belirlenmiştir. Buna göre; kirliliğin yoğun olduğu apartman tipi yapılaşma ile kirliliğin az yoğun olduğu site tipi ve müstakil tip yerleşim alanlarının bulunduğu sokaklar analiz edilmiştir. Bu analizler ile hava kirliliği ve sokak rüzgârı arasında doğrudan ilişki olup olmadığı tespit edilmeye çalışıımıştır. Kirliliğin yoğun ve az yoğun olduğu bölgelerden ağaçlı ve ağaçsız sokak örnekleri üzerinde rüzgâr simülasyonları gerçekleştirilmiştir. Çalışmada belirlenen sokaklar;

(a) Kirlilik oranı az olan ağaçlı sokak olup, KB yöneyinde ve $350 \mathrm{~m}$ uzunluğundadır. Yaklaşık yol genişliği $20 \mathrm{~m}$ ve çevresindeki binalar farklı kat yüksekliklerinde olup 6-9 m'dir.

(b) Kirlilik oranı az olan ağaçsız sokak, GB yöneyinde ve $360 \mathrm{~m}$ uzunluğa sahiptir. Yol genişliği $30 \mathrm{~m}$ ve çevresindeki binaların yüksekliği yaklaşık 18 m'dir. 


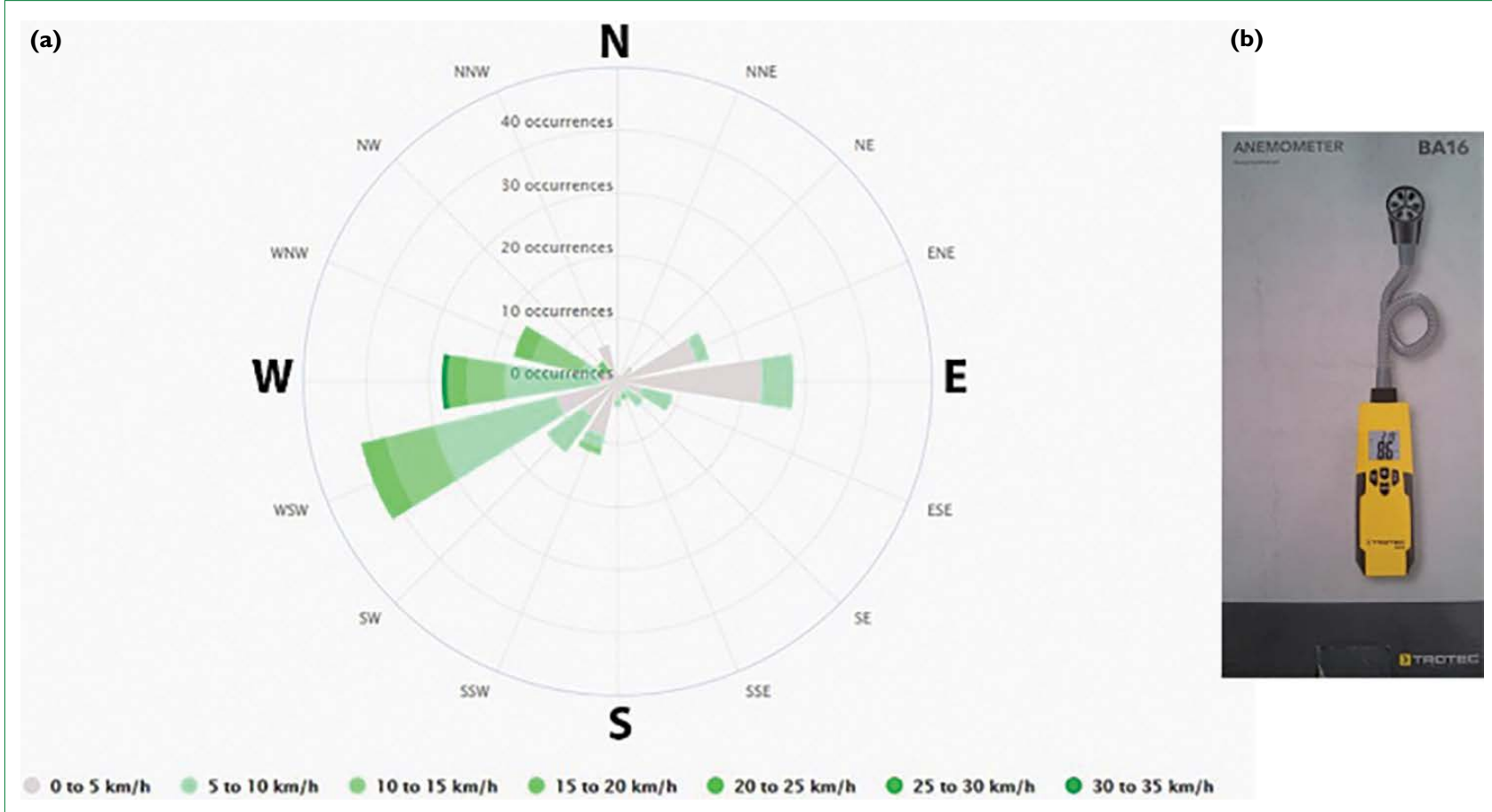

Şekil 3. (a) Erzurum kenti rüzgar gülü. (b) Rüzgar ölçümünde kullanılan alet.

(c) Kirlilik oranı yüksek olan ağaçlı bu sokak $\mathrm{K}$ yöneyli ve 300 m'dir. Yol genişliği $15 \mathrm{~m}$ ve çevresindeki binaların yüksekliği yaklaşık 9-18 m arasında değişmekte olup, genel olarak 15 m'dir.

(d) Kirlilik oranı yüksek olan ağaçsız bu sokak ise KB yönelimli ve $220 \mathrm{~m}$ uzunluğa sahiptir. Yol genişliği $6 \mathrm{~m}$, binalar farklı yüksekliklerdedir. Rüzgâr yönünde olan binaların yükseklikleri 18-15 m aralığında değişmekte, diğer cephede olan bina yükseklikleri ise 9-15 m aralığında değişmektedir.

Sokakların ağaçlı ve ağaçsız olma durumlarına göre analiz edilmiştir. Bu analizler de ArcGIS 10.3 programı rastgele nokta atma yöntemi kullanılarak (Data Management modülülü Feature Class Create Random Point) 4'lü örneklem seçimi yapılmıştır.

\subsection{Rüzgâr ve Gökyüzü Görünürlük Oranı (GGO- Sky View Factor -SVF) Ölçümleri}

Belirlenen dört sokak için, 2018 yılında, rüzgâr, GGO ölçümleri ve gözlemleri mevcut alanda, yerinde yapılmıştır. Kentin uzun yıllar verileri 1998-2018 yılı değerlendirildiğinde Aralık ayı rüzgâr ortalaması $1.88 \mathrm{~m} / \mathrm{s}$, Ocak ayı $1.87 \mathrm{~m} / \mathrm{s}$, Şubat ayı ise $2.21 \mathrm{~m} / \mathrm{s}$ olarak hesaplanmıştır. En yüksek rüzgâr hızı ortalaması Temmuz ayına ait olup $3.56 \mathrm{~m} / \mathrm{s}$, bunu $3.37 \mathrm{~m} / \mathrm{s}$ ile ağustos ayı takip etmektedir. Genellikle rüzgâr hızı kış aylarında düşük olup, uzun yıllar ortalamasına göre rüzgâr hızı $2.7 \mathrm{~m} / \mathrm{s}$ olarak belirlenmiştir. Kentte yaz aylarında rüzgâr hızının daha fazla olduğu ve genellikle DoğuKuzeyDoğu (ENE) eğilimli ol- duğu görülmektedir. Kış aylarında kentte hakim rüzgâr yönü GüneyBatı (SW) olup, genellikle Batı (W) ve BatıGüneyBatı (WSW) olarak değişmektedir (MGM, 2018).

Bu sokakların kanyon özelliğini belirlemek için, farklı 4 noktadan alınan yol genişlikleri ve bina kat yükseklikleri (Y/G) oranlanmıştır. Alan içinde rüzgâr ölçümleri anemometre aleti ile yerden I-I.2 m yüksekte tutularak m/s olarak ölçülmüştür (Şekil 3).

Seçilen sokakların kanyon özelliğinin belirlenmesinde gökyüzü görünürlük oranı (GGO) kullanılmıştır. GGO oranı ise Rayman programı ile hesaplanmakta ve gökyüzü görünürlük oranını ifade etmektedir. GGO değeri 0 ile I arasında rakamlar ile ifade edilmektedir. Sokak kanyonlarında bu değer l'e yaklaştıkca kanyonun genişlediğini, O'a yaklaştıkça kanyonun daraldığını göstermektedir (Algeciras vd., 2016; Qaid vd., 2017; Li vd., 2020). Bu ölçümler alınırken yolun ortasından, kuzeye dönerek ve yerden I-I.2 m yüksekte makinayı gökyüzüne doğru dik tutarak çekimler yapılmıştır. Çekimler sırasında Nikon D5200 kamera ve balık gözü lens (RayPro $52 \mathrm{~mm}$ 0.25X ProHD FishEye+12.5 Diopter Macro Lens) kullanılmıştır. Elde edilen veriler RayMan pro 2.1 ve ArcGIS 10.3 programı kullanılarak kent için GGO haritası hazırlanmıştır (Matzarakis ve Matuschek, 20II; Chen vd., 2012; Yilmaz vd., 2018; Yilmaz vd., 2020).

\subsection{Hesaplamalı Akışkanlar Dinamiği (CFD) Modeli}

Belirlenen sokak kanyonları içerisindeki rüzgâr akışını test etmek için Hesaplamalı Akışkanlar Dinamiği, "Computational 


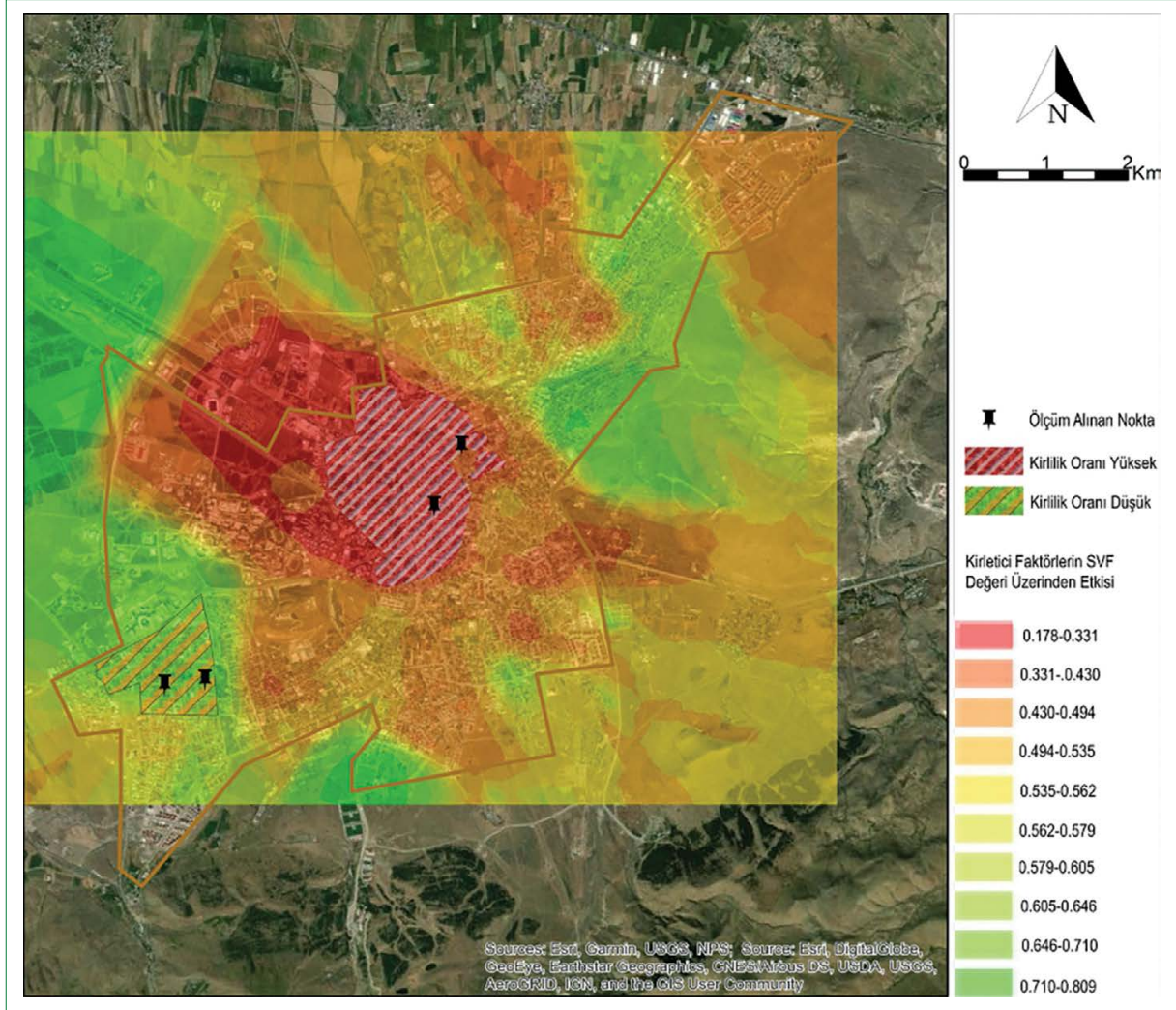

Şekil 4. Hava kirliliğinin yoğunluk durumuna ait mekansal analiz haritası (Yeşilden kırmızıya doğru hava kirliliğinin yoğunlaştı̆ı alanları göstermektedir).

Fluid Dynamics" modeli kullanılmıştır. Hesaplamalı Akışkanlar Dinamiği ANSYS 16.0 programı "Fluent Çözücüsüne Solid Works" programında katı cisimde boşluk olarak " $10 * 20 * 50$ cm dikdörtgen prizma alanı” içerisinde modellenip yüklenmiştir. Çizim geometri modülü ile ANSYS programına tanıtılmıştır. $\mathrm{Bu}$ modüllerde yapılan detaylı işlemler sırası ile yer verilmiştir. Daha sonra program içerisinde yer alan mesh modülü ile tüm alan üçgenlerle tanıtılmıştır. General modülünde havanın taşınım modellerinden doğal taşınım ve rüzgâr tipi seçilmiştir. Benzer hızlarda yapılan simülasyonlar referans alınarak reynolds katsayısına göre türbülans rüzgâr modeli kullanılmıştır. "Boundary condition" modülünde ise havanın giriş-çıkış yönü hakim rüzgâr yönü olan GüneyBatı olarak tanımlanmıştır. Modüller kullanılarak tanıtım işlemi bitirildikten sonra çözme işlemi başlatılmıştır. Solution matematiksel boyutta simple modülüyle çözüm işlemi yapılmıştır. Simülasyon sonuçları rüzgârın vektörel dağılımı incelenerek, rüzgâr ve kirlilik dağılımı arasındaki ilişkisi analiz edilmiştir (Yuan vd., 2014; Sarı ve Yılmaz, 2019; Bendida vd., 2019).

\section{Araştırma Bulguları ve Tartışma}

Gökyüzü görünürlük analiz haritası, emisyon faktörleri, coğrafi veriler (basınç, rüzgâr, sıcaklık ve yükseklik değerleri) ve fiziksel faktörler (doğalgaz ve kömür tüketim verileri, nüfus yoğunlukları) kullanılarak oluşturulan haritalar çakıştırılarak kentin tahmini kirlilik haritası hazırlanmıştır. Kent için hazırla- nan kirlilik haritası üzerinde belirlenen dört farklı sokak analiz edilmiştir. Sokaklar tercih edilirken kirliliğin yoğun ve az yoğun olduğu yerlerdeki ağaçlı ve ağaçsız olma durumlarına dikkat edilmiştir. Bu amaçla elde edilen harita Şekil 4'te verilmiştir. Şekilde görüldüğü gibi kent merkezinde hava kirliliği daha yoğun iken Palandöken Dağı'nın yamaçlarına doğru kirlilik oranının azaldığı görülmektedir. Hava kirliliğinin diğer yoğun olduğu bölge ise kentin Güneyine doğru uzanan ova ve buradaki yerleşim yerlerinin olduğu kısımlardır. Nitekim burada rakımının daha düşük ve yüzeyin çukurda olması kirliliğin burada yoğunlaşmasını da desteklemektedir. Bu harita üzerinde kirliliğin yoğun olduğu ve az yoğun olduğu iki farklı yerleşim alanı işaretlenmiştir. Erzurum kentine ait hava kirliliği sentezi haritasından hava kalitesi açısından yaşam konforunu engelleyen (hava kirliliği yoğun olan) bölgesi ve yaşam konforunu destekleyen (hava kirliliği az olan) bölgesi olarak ifade edilmiştir.

Şekil 4'te beyaz çizgili gösterilen alan kent merkezinde kirliliğin yoğun olduğu alanı, turuncu çizgili yer ise Palandöken Dağına doğru kirliliğin az yoğun olduğu mekânları ifade etmektedir.

\section{I Sokaklarda Rüzgâr Senaryolarının Analizi}

Hava kirliliği yoğunluğuna göre; yaşam konforunu destekleyen ve desteklemeyen alanlarda belirlenen dört farklı sokakta rüzgâr akışını belirleyen analizler yapılmıştır (Şekil 5). 

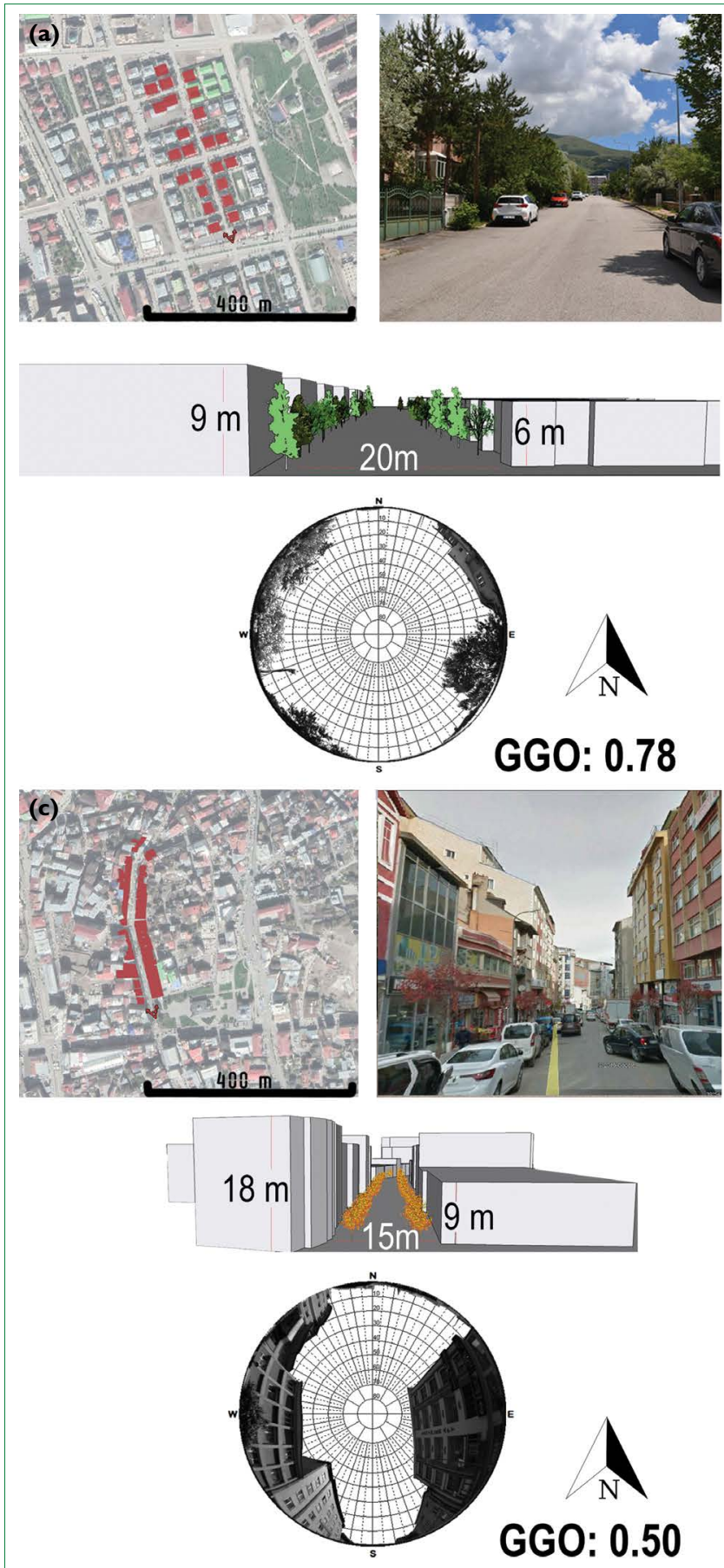
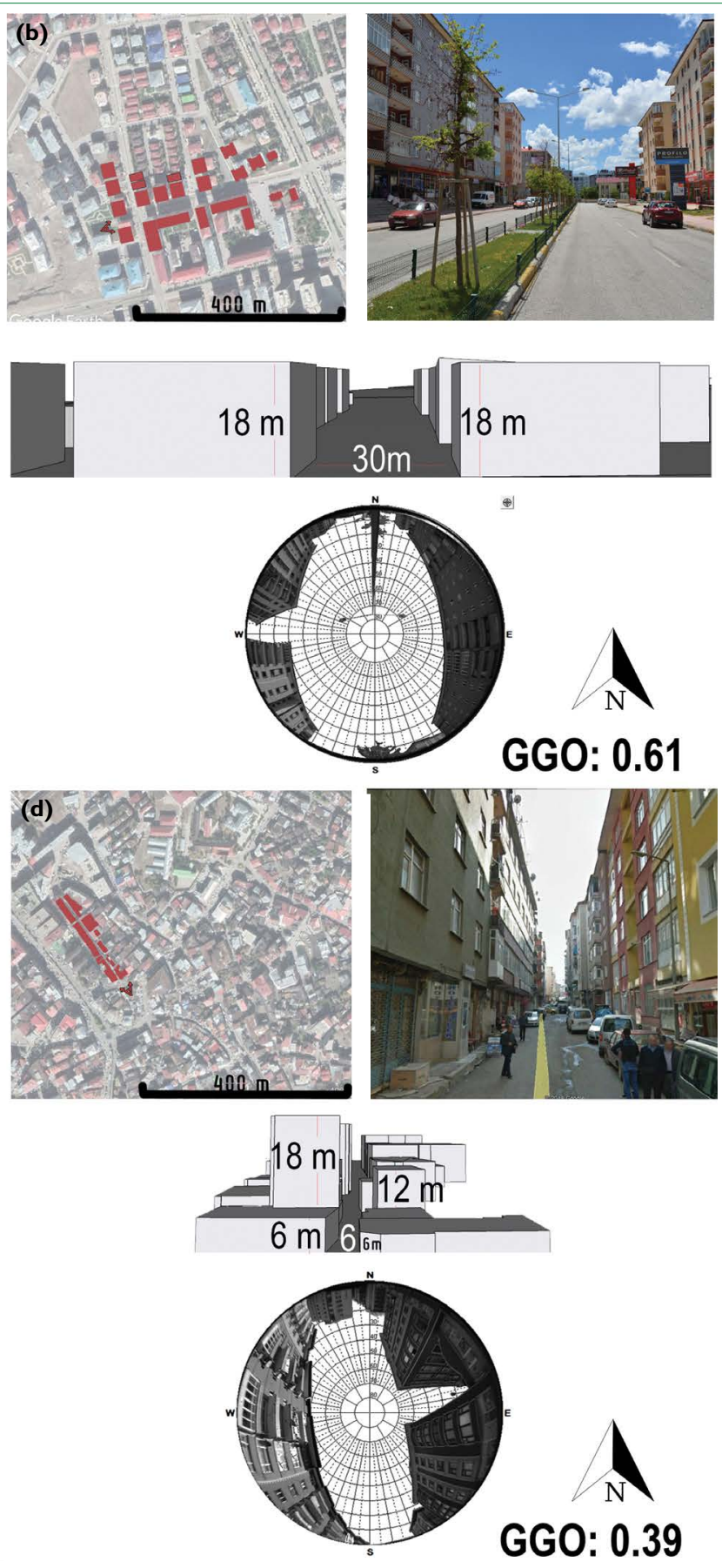

Şekil 5. Analizleri yapılan sokakların özellikleri, sokak. (a) kirlilik oranı az ağaçıı sokak. (b) Kirlilik oranı az ağaçsız sokak. (c) Kirlilik oranı yüksek ağaçlı sokak. (d) Kirlilik oranı yüksek ağaçsı sokak).

Belirlenen bu dört sokağın özellikleri ve analizleri Tablo I'de verilmiştir. Her bir sokak için ayrı ayrı CFD modeli uygulanarak rüzgâr akış simülasyonları yapılmıştır. Bu model kullanılarak farklı sokak özelliklerine göre rüzgâr hareketliliği analiz edilebilmektedir. Böylece planlama çalışmalarında kullanılması ile daha yaşanabilir mekân tasarımlarının desteklenmesi sağlanabilecektir (Bendida at al., 2019). Hava kirliliğinin az yoğun ve yoğun olduğu sokaklarda ağaçların rüzgâr hareketliliğini nasıl etkilediği analiz edilmiştir.

(a) Kirlilik oranı az ağaçlı sokak: Şekil 5 a için yapılan analize göre; kanyon içerisindeki rüzgâr hızı düşüşe uğramamakta, vejetasyon varlığı rüzgârın yönlenmesine ve hızına olumlu yönde etki etmektedir (Şekil 6). Berardi vd., 2014'un 
Tablo I. Sokak özellikleri analizi

\begin{tabular}{|c|c|c|c|c|c|c|c|c|}
\hline Sokak & $\begin{array}{c}\text { Hava } \\
\text { kirliliği }\end{array}$ & $\begin{array}{l}\text { Bitki } \\
\text { varlığı }\end{array}$ & $\begin{array}{c}\text { Sokak } \\
\text { uzunluğu }\end{array}$ & $\begin{array}{l}\text { Y/G } \\
\text { oranı }\end{array}$ & $\begin{array}{l}\text { Bina aralıkları/ } \\
\text { bölünme }\end{array}$ & GGO & $\begin{array}{c}\text { Çatı seviyesi } \\
\text { farkı }\end{array}$ & Sokak yönü \\
\hline (a) & $\mathrm{Az}$ & Ağaçlı & 350 & 0.4 & 15 m (18) & 0.78 & $\% 25$ & $\begin{array}{c}\mathrm{KB} \\
\text { (öğleden sonra) }\end{array}$ \\
\hline (b) & $\mathrm{Az}$ & Ağaçsız & 360 & 0.6 & $10 \mathrm{~m}(12)$ & 0.61 & $\% 23$ & $\begin{array}{l}\text { GB (sabah } \\
\text { güneşi) }\end{array}$ \\
\hline (c) & Yoğun & Ağaçlı & 300 & 1.0 & $8 \mathrm{~m} \mathrm{(6)}$ & 0.50 & $\% 57$ & $\mathrm{~K}$ \\
\hline (d) & Yoğun & Ağaçsız & 220 & 2.5 & 8 m (4) & 0.39 & $\% 29$ & $\begin{array}{l}\text { KB (öğleden } \\
\text { sonra) }\end{array}$ \\
\hline
\end{tabular}

Y/G: Yüksekliğin genişliğe oranı; GGO: Gökyüzü görünürlük oranı; KB: Kuzeybatı; GB: Güneybatı; K: Kuzey.
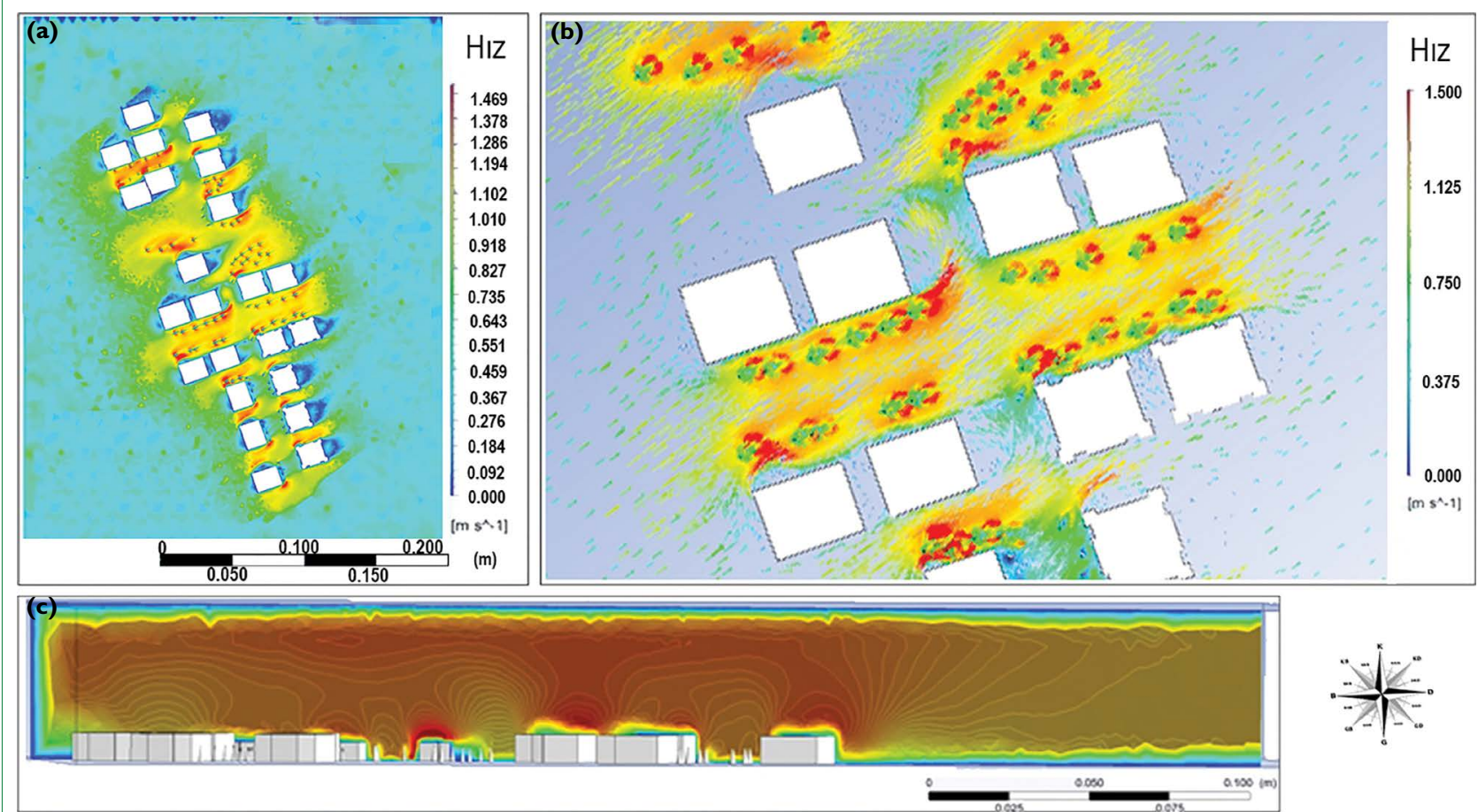

Şekil 6. (a) Sokak kanyonunda rüzgarın dağılımı plan ölçeğinde. (b) Rüzgarın planda vektörel dağıımı. (c) Sokak kesitinde rüzgarın vektörel dağıımı.

yaptığı çalışmalarda da ağaçların pozitif katkısını vurgulamıştır. Güneydoğudan (GD) gelen rüzgâr, kanyon içerisinde ağaca çarpıp durmakta daha sonra daha hızlı bir şekilde ağacın yerleştirildiği yöne doğru hareket etmektedir. Normal şartlarda ise binaların arkasında rüzgârın değişime uğramadığı belirlenmiştir (Şekil 6b).

(b) Kirlilik oranı az ağaçsız sokak: Şekil 5 b için yapılan analize göre; kanyon içerisindeki rüzgâr hızının $0.25 \mathrm{~m} / \mathrm{s}$ ile $0.8 \mathrm{~m} / \mathrm{s}$ arasında değişiklik gösterdiği saptanmıştır. Rüzgârın yön değiştirmesini sağlayacak herhangi bir unsur olmadığı için tek engel olan yapılara çarpmakta ve akışına aynı yönde devam etmektedir (Şekil 7). (c) Kirlilik oranı yüksek ağaçlı sokak: Şekil 5c için yapılan analize göre; kanyon içerisindeki rüzgâr hızı yapılardan dolayı düşüşe uğramakta, balkon, çatı ve araç gibi engellerden dolayı ise durma noktasına gelmektedir. Güneydoğudan gelen rüzgâr sınırlı sayıda boşluktan kanyon içerisine girmekte ancak kanyon içerisindeki unsurlara çarpan rüzgârın hareket alanı da kısıtlı olması nedeniyle durmaktadır (Şekil 8). Aslında burada bulunan ağaçlar süs ağaçları olup, kışında yapraklarını dökmektedirler. Burada rüzgârın hareketliliğini sınırlayan caddedeki kırılma, yapılar arası boşluk olmaması olarak gösterilebilir.

(d) Kirlilik oranı yüksek ağaçsız sokak: Şekil $5 d$ için yapılan analize göre; kanyon içerisindeki rüzgâr hızı düşüşe 

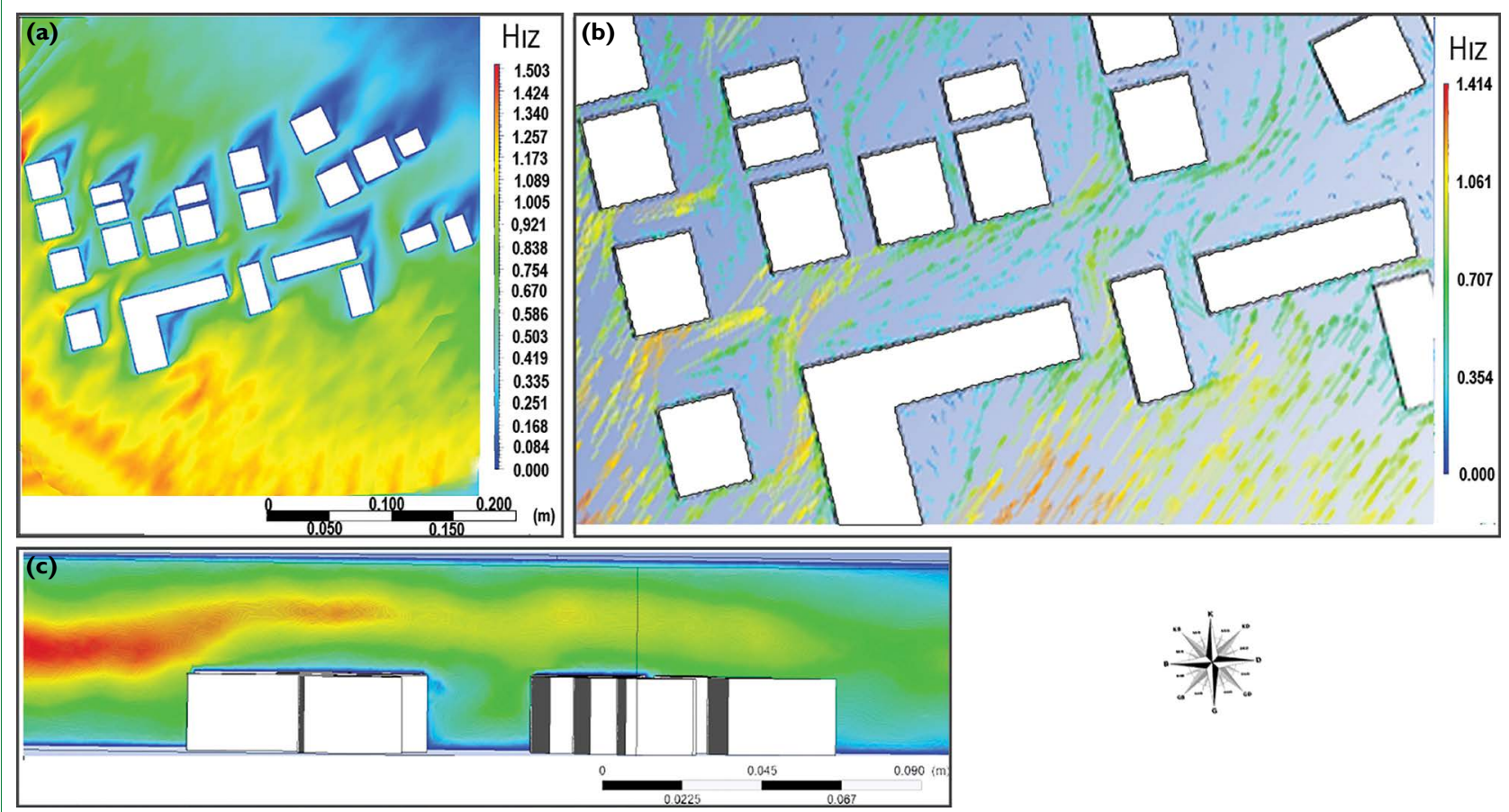

Şekil 7. (a) Sokak kanyonunda rüzgarın dağıımı plan ölçeğinde. (b) Rüzgarın planda vektörel dağıııı. (c) Sokak kesitinde rüzgarın vektörel dağıımı.

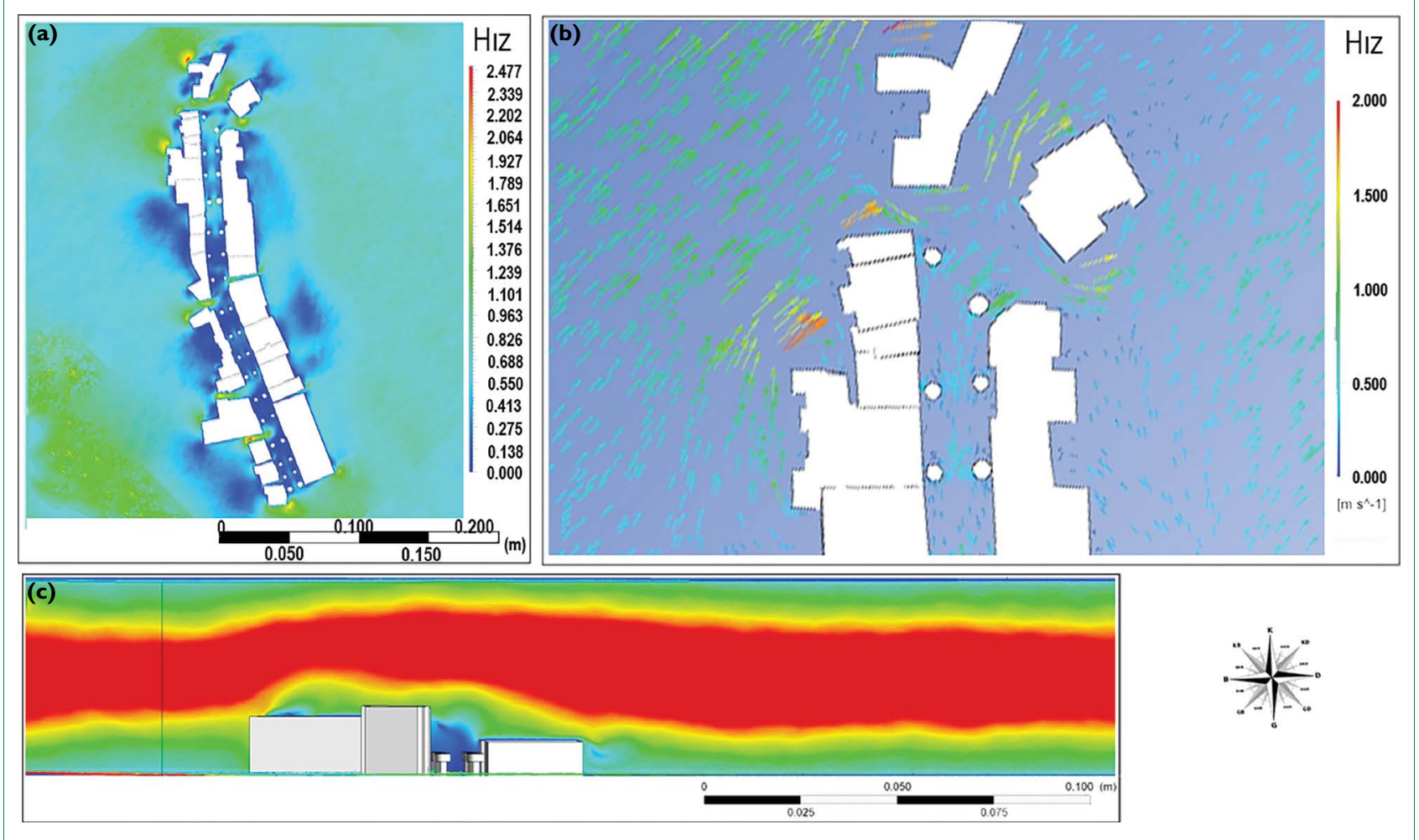

Şekil 8. (a) Sokak kanyonunda rüzgarın dağıımı plan ölçeğinde. (b) Rüzgarın planda vektörel dağıımı. (c) Sokak kesitinde rüzgarın vektörel dağıımı.

uğramakta ve durma noktasına gelmektedir. Binalar arasındaki boşluktan giren rüzgâr kanyon içerisinde hareket etmemekte doğrudan karşısındaki boşluktan çıkış yapmaktadır.
Binaların rüzgârın geliş yönüne dik olarak konumlandırılmış olması kanyon içerisinde rüzgârın kavitasyon yapmasına neden olmakta ve rüzgâr hareketine engel olmaktadır. Rüzgâr 

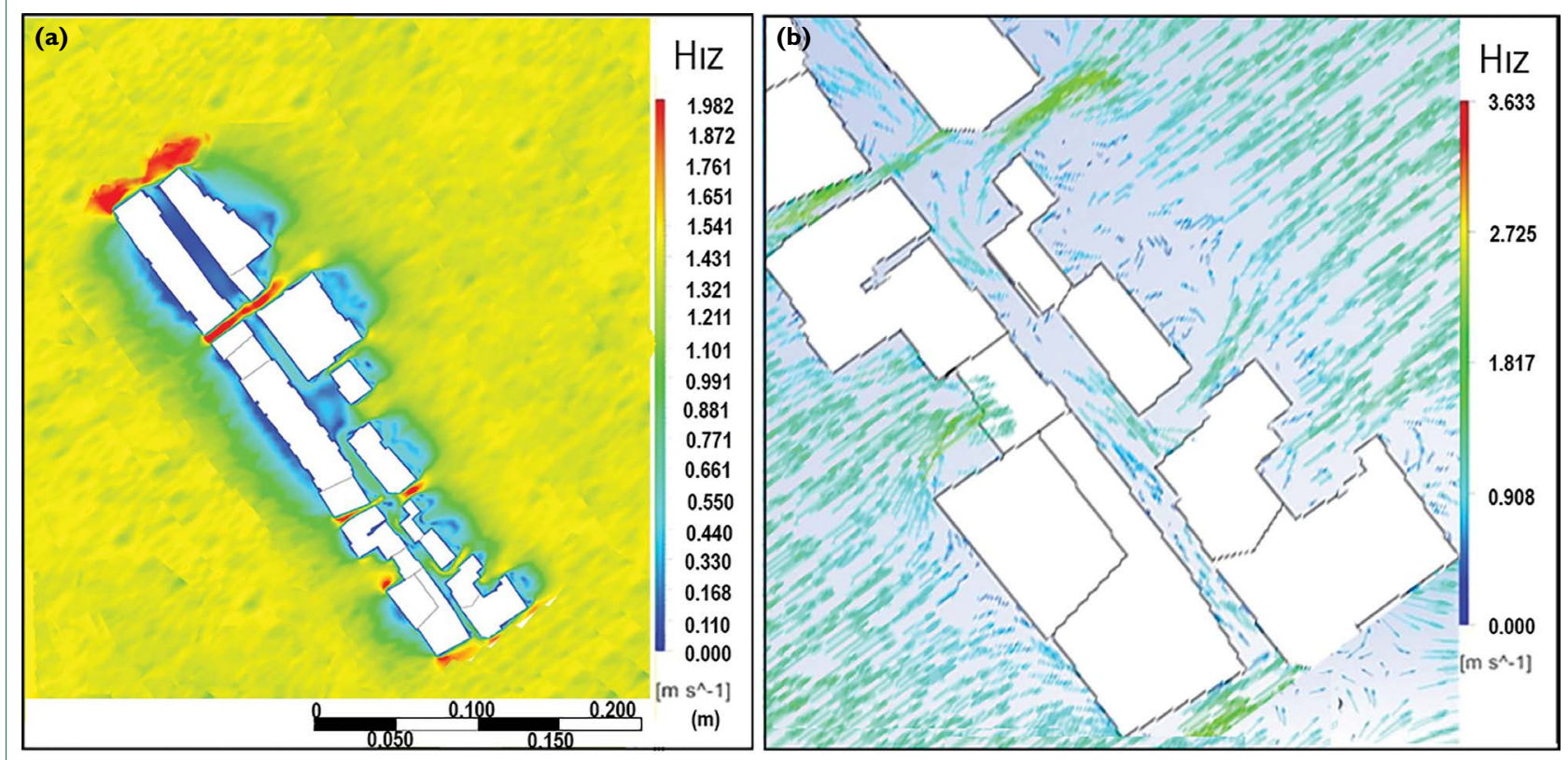

(c)
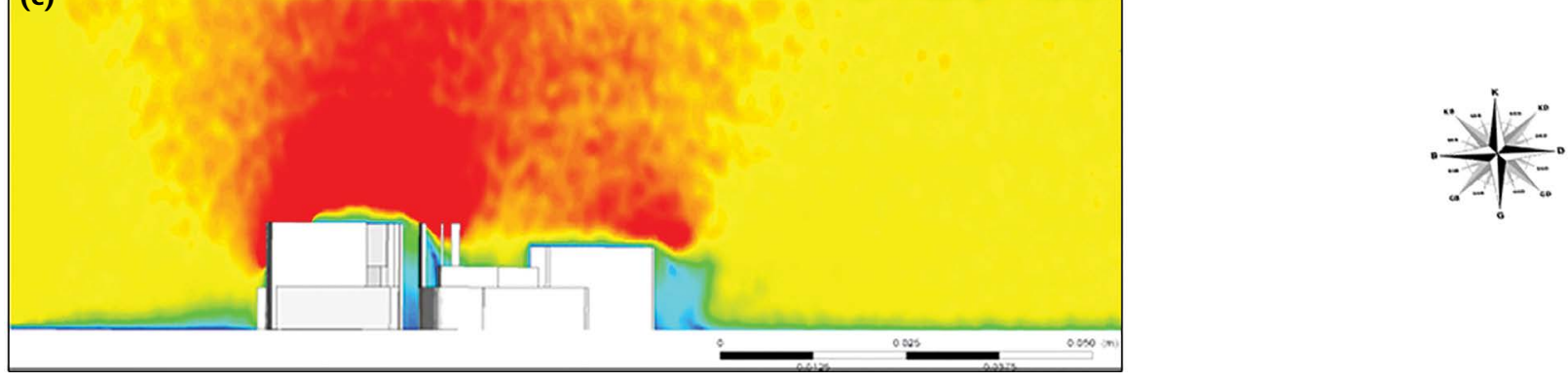

Şekil 9. (a) Sokak kanyonunda rüzgarın dağıımı plan ölçeğinde. (b) Rüzgarın planda vektörel dağııımı. (c) Sokak kesitinde rüzgarın vektörel dağıımı.

sokağa dik olarak girmekte fakat yüksek boylu yapılar ve binalar arası mesafenin az olması nedeniyle sokakta hareket edememektedir (Şekil 9).

Analiz yapılan sokak kanyonlarında Y/G oranı genel olarak 0.4 'ün üstünde elde edilmiştir. Bu da genellikle dar ve dara yakın sokak kanyonlarına ait özelliği göstermektedir. Sokak uzunluğu açısından incelendiğinde ise $220 \mathrm{~m}$ ve $360 \mathrm{~m}$ arasında değiştiği gözlemlenmiştir. Sokak uzunluklarının fazla olmasının kanyon etkisini ve kirletici dağııımını zorlaştırdığı bilinmektedir. Uzunluğun diğerlerine göre kısa olduğu 220 m uzunluğundaki kirlilik oranının yüksek olduğu sokak, yükseklik/genişlikten kaynaklanan kanyon etkisinin ve sokak yönünün daha baskın parametreler olduğunu göstermektedir. Nitekim yapılan bir araştırmaya göre, güneş ışı̆̆ından en iyi yararlanılacak sokak kanyon oranları belirlenmiştir. Buna göre, sıcak iklim bölgelerinde bu oranın $Y / G \geq 0.5$ 'den büyük dar kanyon sokaklar şeklinde, soğuk iklim bölgeleri için ise bu oranın Y/G $\leq 0.5$ 'den küçük geniş kanyon sokak özelliklerini içerecek şekilde planlanması gerektiği belirtilmiştir (Shishegar, 2013; Bendida at al., 2019). Yine yapılan bir araştırmada, dar kanyon özelliği gösteren ve değeri $Y / G \geq 0.5$ 'den büyük olan sokaklarda ağaçların kullanılmasının rüzgârı etkilediği ve bununda termal konfora olumsuz yansıdığı belirtilmiştir (Ali-Toudert ve Mayer, 2006). Nitekim bu çalışmada da dar kanyon özelliği gösteren (c) ve (d) sokaklarında rüzgâr hareketliliğinin kısıtlı olmasından dolayı hava kirliliğinin yoğun olduğu görülmüştür.

Kanyonlarda çatı seviyesinde ve yaya seviyesinde rüzgâr hızı değerleri alınmıştır. Çatı seviyesindeki akışın yaya seviyesine göre hızlı olduğu saptanmıştır. Kanyon içerisinde yaya seviyesinde rüzgâr hızı I m/s'ye kadar yükselebilmekte çatı seviyesinde rüzgâr hızı I m/s ve 2.5 m/s arasında değişmektedir. Ayrıca sokak yönlenmeleri değerlendirildiğinde hakim rüzgâr yönüne paralel sokak olmadığı da incelenmiştir. Oysa yapılan çalışmalarda hakim rüzgâr yönüne paralel sokakların olması rüzgâr akışını kolaylaştırdığı belirtilmiştir (Gallagher vd., 2015). Dört faklı sokak için bina çatısı ve yaya seviyesinde rüzgâr simülasyonları yapılmıştır. Elde edilen verilere ait grafik Şekil I0'da verilmiştir.

Hava kirliliğinin az olduğu ağaçlı (a) sokak kanyonunda rüzgâr hızının sokak içerisine girdiğinde düşüş yaşadığı ancak içerideki 

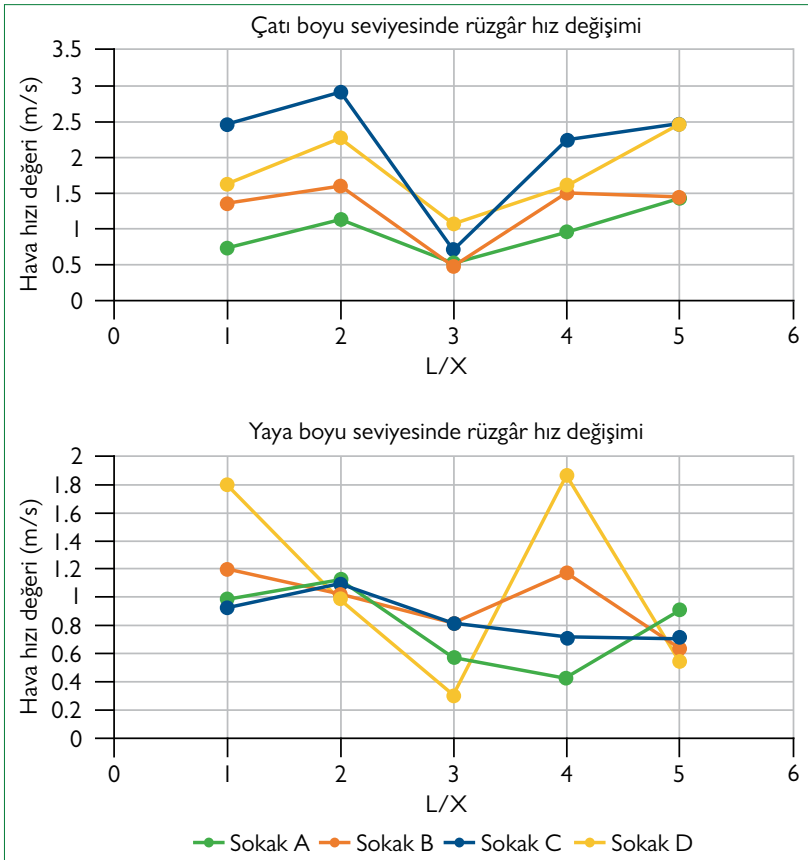

Şekil 10. Yaya seviyesi ve çatı seviyesinde rüzgar akışı. Sokak (a) Kirlilik az ağaçlı sokak. Sokak (b) Kirlilik az, ağaçsız sokak. Sokak (c) Kirlilik az, ağaçlı sokak. Sokak (d) Kirlilik az, ağaçsız sokak.

vejetasyon yardımıyla hız kazandığı saptanmıştır. Burada kullanılan ağaçların yüksekten dallandığı, geçirgen ve şeffaf dokulu olduğu belirlenmiştir. Çatı seviyesi ile yaya seviyesi arasındaki rüzgâr hızında \%25 azalma incelenmiştir. KB yönünde olan sokağın uzunluğu $350 \mathrm{~m}$ olup binalar arası mesafe 15 'er metredir. Toplamda sokak 18 kez ara sokaklar ile kesilmiştir. Normal şartlarda rüzgârın içeri girmesi olası olmayan durumlarda bitki varlı̆ıı rüzgârın içeriye girmesine neden olmaktadır. Bitki örtüsünün alttan dallanan, yoğun dokulu ve blok etkisi oluşturmayan türlerden seçilmiş olması da sokak rüzgârın dolaşımını olumlu yönde etkilemiştir. Benzer sonuçlar; (Buccolieri vd., 2010; Salim vd., 20II; Gallagher vd., 2015; Janhäll, 20I5) çalışmalarında da görülmüştür. Bu durum hava kirleticilerinin de dağılmasını dolayısıyla hava kalitesini de olumlu yönde etkilemektedir. Ayrıca, Wania vd'nin (20I2) yaptığı çalışmada ağaçların kirlilik ve partikül madde tutmada olumlu katkı sağladığı belirlenmiştir. Bu sokak kanyonunun GGO yani sokağın geniş olması da kirliliğin dağılımında önemli bir etken olarak görülmüştür. Nitekim GGO, sokak yönü ve açısı ile ilgili yapılan çalışmalarda da rüzgârın etkilendiği ifade edilmiştir (Zhang vd., 2015; Yilmaz vd., 2018). Ağaçlar hava akışlarını kontrol ederek, rüzgâr hızını azaltarak veya yön değiştirerek mikro klimatik koşulları etkilemektedir (Perini vd., 2018). Ağaçların veya vejetasyonun bu olumlu katısı farklı araştırmalar ile de belirlenmiştir (Lee vd., 2020).

Kirliliğin az olduğu ağaçsız olan (b) sokakta rüzgârın kanyonuna girdikten sonra kısmen yavaşladığı, çatı seviyesinden farklı olarak ise rüzgâr hızında \%23 azalma olduğu belirlenmiştir. GB yönelimli olan bu sokağın uzunluğu $360 \mathrm{~m}$ olup binalar arası mesafe 10'ar metredir. Toplamda sokak $12 \mathrm{kez}$ ara yollar ile kesilmiştir. Sokak genişliğinin $10 \mathrm{~m}$ den fazla olması ve gökyüzü açıklı̆ının fazla olması durumunda, benzer çalışmalarda da kanıtlandığı gibi hava kirliliği dağıımını olumlu yönde etkilemektedir (Fu vd., 2017; Taseiko vd., 2009). Nitekim bu sokakta $30 \mathrm{~m}$ genişliğinde ve GGO bakımından da geniş kanyon özelliği taşımaktadır. Rüzgâr yönüne paralel olarak planlanan sokaklarda hava akımı daha iyi olurken dar ve dolambaçlı yollarda rüzgâr hızı kesilmektedir (Shishegar, 2013; Shi vd., 20I8). Hava kirliliğinin az yoğun olduğu bu sokağın doğu-batı yöneyine daha yakın bir yerleşim gösterdiği görülmektedir. Nitekim yapılan bir araştırmada, Doğu-Batı yönelimli, geniş kanyon özelliği gösteren caddelerin güneş ışığından daha uzun süre yararlandıkları belirlenmiştir (Ali-Toudert ve Mayer, 2006). Bununda kış ayları için geniş kanyon özelliği sağlayan (b) sokağına avantaj sağladığı görülmektedir.

Kirliliğin yoğun olduğu bölgede ağaçlı (c) sokak kanyonu incelendiğinde $300 \mathrm{~m}$ uzunluğunda Kuzey yönelimli sokak boyunca yapılar arası mesafe $8 \mathrm{~m}$ ve toplamda $6 \mathrm{kez}$ ara yollar ile kesildiği belirlenmiştir. Rüzgâr hızı ise çatı seviyesine oranla yaya seviyesinde \%57 düşüş incelenmiştir. Bu rüzgâr hızındaki azalmanın kısmen ağaçlardan kaynaklandığı belirlenmiştir. Nitekim farklı araştırmalarda da ağaçların rüzgâr hızını kestiği ifade edilmiştir (Gallagher vd., 20I5; Gromke ve Blocken, 2015; Li vd., 2019). Ancak burada kullanılan ağaçlar süs ağaçları olup, kışında yapraklarını dökmektedirler. Burada caddenin ucunda görülen kırılma, yapılar asası mesafenin olmaması veya çok az olması, dar kanyon özelliği taşıması etken faktör olarak gösterilebilir.

Kirliliğin yoğun olduğu, ağaçsız (d) sokak kanyonunda rüzgâr akış simülasyonu incelendiğinde çatı seviyesindeki rüzgâr hızında \%29 düşüş saptanmıştır. Kanyon içesindeki rüzgâr hareketinin ise durma noktasında olduğu görülmüştür. Sokak kanyonlarında CFD ile yapılan analizde kanyon değerinin 0.7 'den büyük olması durumunda (Klemm ve Heim 2009) ve dar kanyonlarda rüzgârın sokakta sıkışıp kaldığı ve girdap etkisi oluşturduğu belirlenmiştir (Yuan vd., 2014). Nitekim Yuan vd.de (20I4) Hong Kong'da CFD ile yapılan bir çalışma sonucunda, dar kanyon özelliği gösteren (Y/G) 0.5 'den büyük olan sokaklarda hava kirliliğinin sıkışarak mekânda kaldığı belirlenmiştir. Rüzgâr analizi yapılan bir araştırmada yaya seviyesinde rüzgârın hızında $0.3 \mathrm{~m} / \mathrm{s}^{\prime}$ lik azalma olduğu belirlenmiştir (AliToudert ve Mayer, 2006).

KuzeyBatı yönünde $220 \mathrm{~m}$ sokak uzunluğu boyunca yalnızca 4 kez ara yollar ile kesilmiş olması rüzgârın içeriye girmesine engel olmaktadır. Sokak kanyonunun özelliklerinin hava kirliliğinin dağılımında önemli etken olduğu Shi vd. (2018) tarafından da belirlenmiştir. Yapılar arası mesafe $8 \mathrm{~m}$ olarak hesaplanmıştır. Konut yüksekliklerinde heterojenliğin söz konusu 
olması ise çatı seviyesi ve yaya seviyesinde yüksek düşüş farkını engellemiştir. Şekil 5d'deki sokak üzerinde heterojen bina yoğunluğuna sahip olmasına rağmen yapılan analizde rüzgâr hızının düştüğü tespit edilmiştir. Bunun nedeni olarak yüksek binaların rüzgâr yönüne doğru konumlanmış olması ve binalar arası mesafenin az ve yeterli sıklıkta olmaması gösterilebilir. Ayrıca bu sokağın Tablo I'de görüldüğü gibi 2.5 (Y/G) gibi bir oranla dar kanyon özelliği göstermesi de hava kirliliğinin burada bloke olmasına neden olmaktadır.

\section{Sonuç}

Çalışma kapsamında hava kirliliğinin az ve yoğun olduğu bölgelerin karakteristik özellikleri incelenerek karşılaştırmalar yapılmıştır. Mevcut kentsel yapılı alanlarda mekâna ait verilerle CFD simülasyon çalışması sonrası alansal tahmini tutarlılı̆̆ test edilmiş ve sonuçlar tutarlı bulunmuştur. Bu doğrultuda kirliliğe etki eden mekânsal faktörler simülasyon sonucuna göre değerlendirilmiştir. Bu kapsamda; rüzgârın geliş yönü, rüzgâr hızı, bina yükseklikleri, binalar arası mesafe, ağaçlar, sokak kanyon özelliği gibi faktörler rüzgârı yönlendirerek, kirletici dağılımını etkileyen önemli parametreler olarak belirlenmiştir.

Kirliliğin az olduğu sokak kanyonu özelliğine sahip mekânlar ile kirliliğin yoğun olduğu sokaklar karşılaştırıldığında bitki varlığının, rüzgâr hızının azalmasına neden olan önemli bir parametre olduğu bulunmuştur. Dar kanyon özelliği taşıyan sokaklarda, kompakt yapılı ağaçlar rüzgârın hızına ve yönüne etki ederek hava kirliliğinin sokaktan uzaklaştırılmasına veya bloke olmasına neden olmaktadır. Kirliliğin fazla ve az olduğu sokaklardaki ağaç varlığı dokusu karşılaştırıldığında ise yapı parametrelerinin uygun koşulları hazırladığı takdirde hava kirliliği açısından seyreltici ancak kanyon karakteristiği göstermesi durumunda vejetasyon dokusu kirliliği tetikleyici (bina yüksekliği ve binalar arası mesafeden sonra) olduğu belirlenmiştir. Burada seçilen bitki türleri çok önemlidir. Yüksekten dallanan geçirgen özelliğe sahip, ince tekstürlü ağaç türleri rüzgârı geçirirken, yoğun yapraklı, sıkı dokulu, kompakt ağaçlar rüzgârı engellemektedir.

Alanda yapılan gözlemlere göre, özellikle kış aylarında KuzeyDoğu (NE)-GüneyBatı (SW) yönelimli sokakların sabah güneş ışı̆̆ını daha iyi alırken, KuzeyBatı (NW)-GüneyDoğu (SE) yönelimli sokakların öğleden sonra güneş ışığını daha iyi aldığı belirlenmiştir. Sokaklar konumlandırılırken bu özellikler dikkate alınarak planlanmalı ve güneş enerjisinden maksimum yararlanma esas alınmalıdır. Buda kışın ısınma amaçlı binalarda kullanılan fosil yakıtın tüketimini azaltacaktır.

Kirliliğin yoğun olduğu, dar kanyon özelliğine sahip sokaklarda bina yükseklikleri ve binalar arası mesafe olmaması kirliliği bloke eden önemli bir parametre olarak gözlemlenmiştir. Bu alanlarda rüzgârın mekân içine giremediği ve hareketinin kısıtlandı̆̆ı saptanmıştır.
Şekil I0'da yaya seviyesinde ve çatı seviyesinde rüzgâr hızı değişimi verilmiştir. Yaya seviyesinde rüzgâr hızı hem yaya konforunu hem de partikül maddelerin dağılımını etkilemektedir. Bu grafikler karşılaştırıldığında kirliliğin yoğun olduğu ağaçsız sokakta rüzgâr hızı en düşük seviyeye ulaşmaktadır. Kirliğin az olduğu ağaçsız sokakta ise rüzgâr hızı 2 kat daha fazladır. Kirliliğin hem az hem de yoğun olduğu bölgede ise rüzgâr hızı $0.8 \mathrm{~m} / \mathrm{s}^{\prime} d e$ sabitlenmektedir. Kirliliğin yoğun olduğu ağaçlı sokaktan \%27, kirliliğin az olduğu ağaçlı sokaktan \%।4 daha hızlı olduğu tespit edilmiştir. Bu durum sokak yönlenmelerinin rüzgâr yönüne doğru yapılmadığı ve tasarım standartlarına uyulmadığı takdirde ağaçların rüzgâr hızının yavaşlatılmasına etki eden önemli bir parametre olduğunu göstermektedir.

Sokaklarda bitkisel tasarım yapılırken hava kirliliği ve rüzgâr parametrelerinin göz önünde bulundurulması gerekmektedir. Kentsel tasarım standartları açısından bakıldığında Erzurum kenti için sokakların rüzgâr yönüne paralel olması önem arz etmektedir. Kentsel yenileme ve kentsel dönüşüm alanlarında, sokak tasarımlarında hava kalitesini dikkate alan senaryolar geliştirilmeli ve simülasyonlar sonucu yerleşim alanları planlanma kriterleri belirlenmelidir. Nitekim yapılan analizlere göre, şehir planlama ve peyzaj tasarım çalışmalarında mekânın doğal özellikleri dikkate alındığında ortamın koşullarının iyileşebileceği belirlenmiştir. Bunun sağlanması da yaşanabilir yaya dostu sokak tasarımları için oldukça önemlidir.

\section{Teşekkür}

Bu çalışmanın bir sokağını içeren görsel, Elif Nur Sarı tarafından "Definition of Pedestrian Friendly Street Parameters and Evaluation in the Case of Erzurum City. XXIV International Conference, Oral presentation, LWC 2019, Pedestrian,Urban Space and Health-Living and Walking in Cities, 12-13, September 2019, Brescia-ITALY” sempozyumunda sunulmuş ve bildiri tam metin kitabında yer almıştır. Sokakların rüzgâr simülasyonları (CFD) Atatürk Üniversitesi-Mühendislik Fakültesi desteği ile yapılmıştır. 


\section{KAYNAKLAR}

Akbari, H., Pomerantz, M., \& Taha, H. (2001). Cool surfaces and shade trees to reduce energy use and improve air quality in urban areas. Solar Energy, 70(3), 295-310.

Ali-Toudert,F., Mayer, H. (2006). Numerical study on the effects of aspect ratio and orientation of an urban street canyon on outdoor thermal comfort in hot and dry climate. Building and Environment, 41, 94-108.

Akkar E. M., \& Belge, Z. S. (2017). Daha yaşanabilir kentler için mikro ölçek bir yürünebilirlik modeli. Metu Journal of the Faculty of Architecture, 34(1), 231-265. https://doi.org/10.4305/METU.JFA.2016.2.11.

Aksu, A., Yılmaz, S., Mutlu, B.E, Yılmaz, H. (2020). Ağaçların Bina ile Olan Mesafesinin Dış Mekan Termal Konfor Üzerine Etkisi: Erzurum Kenti Örneği. Iğdır Üni. Fen Bilimleri Enstitüsü Dergisi, 10 (2), 1298-1307, DOI: $10.21597 /$ jist.635503.

Algeciras, J. A. R., Consuegra, L. G., \& Matzarakis, A. (2016). Spatial-temporal study on the effects of urban street configurations on human thermal comfort in the world heritage city of Camagüey-Cuba. Building and Environment, 101, 85-101.

Balczó, M., Gromke, C., \& Ruck, B. (2009). Numerical modeling of flow and pollutant dispersion in street canyons with tree planting. Meteorologische Zeitschrift, 18(2), 197-206.

Balogun, A. A., Tomlin, A. S., Wood, C. R., Barlow, J. F., Belcher, S. E., Smalley, R. J., Robins, A. G. (2010). In-street wind direction variability in the vicinity of a busy intersection in central London. Boundary-Layer Meteorology, 136 (3), 489-513.

Berardi, U., GhaffarianHoseini, A., \& GhaffarianHoseini, A. (2014). Stateof-the-art analysis of the environmental benefits of green roofs. Applied Energy, 115, 411-428.

Bendida, M.,Djellouli A., Hamidat D., Bouzit, M., (2019). Structure of the out- flows behind buildings and Influence of the geometry of the streets on the out-flows. Journal of Materials and Engineering Structures, 6, 375-382.

Buccolieri, R., Sandberg, M., \& Di Sabatino, S. (2010). City breathability and its link to pollutant concentration distribution within urban-like geometries. Atmospheric Environment, 44(15), 1894-1903. https://doi. org $/ 10.1016 /$ j.atmosenv.

Canan, F. (2017). Kent geometrisine bağlı olarak kentsel 1sı adası etkisinin belirlenmesi: Konya örneği. Çukurova Üniversitesi Mühendislik-Mimarlık Fakültesi Dergisi, 32(3), 69-80. https://doi.org/10.21605/cukurovaummfd.357202.

Chen, L., Ng, E., An, X., Ren, C., Lee, M., Wang, U., He, Z. (2012). Sky view factor analysis of street canyons and its implications for daytime air temperature differentials in high-rise, high-density urban areas of Hong Kong: a GIS-based simulation approach. International Journal of Climatology, 32(1), 121-136.

Clark, L. P., Millet, D. B., \& Marshall, J. D. (2011). Air quality and urban form in U.S. urban areas: Evidence from regulatory monitors. Environmental Science and Technology, 46 (16), 7028-7035, https://doi.org/10.1021/ es2006786.

DePaul, F. T., \& Sheih, C. M. (1986). Measurements of wind velocities in a street canyon. Atmospheric Environment (1967), 20(3), 455-459.

Dursun, D. \& Yavaş, M., 2017. Soğuk iklime duyarlı kentsel tasarım yaklaşımları, Iğdır Üniversitesi Fen Bilimleri Enstitüsü Dergisi,7(2), 269-278.

Eskridge, R. E., \& Rao, S. T. (1986). Turbulent diffusion behind vehicles: experimentally determined turbulence mixing parameters. Atmospheric Environment, 20(5), 851-860.

Fu, X., Liu, J., Ban-Weiss, G. A., Zhang, J., Huang, X., Ouyang, B., Tao, S. (2017). Effects of canyon geometry on the distribution of traffic-related air pollution in a large urban area: Implications of a multi-canyon air pollution dispersion model. Atmospheric Environment, 165, 111-121. https://doi.org/10.1016/j.atmosenv.2017.06.031.
Gallagher, J., Baldauf, R., Fuller, C. H., Kumar, P., Gill, L. W., \& Mcnabola, A. (2015). Passive methods for improving air quality in the built environment : A review of porous and solid barriers. Atmospheric Environment, 120, 61-70. https://doi.org/10.1016/j.atmosenv.2015.08.075.

Gromke, C., \& Blocken, B. (2015). Influence of avenue-trees on air quality at the urban neighborhood scale. Part II: Traffic pollutant concentrations at pedestrian level. Environmental Pollution, 196, 176-184. https://doi. org $/ 10.1016 / \mathrm{j}$.envpol.2014.10.015.

Gültekin, N.T. (2005). Geleneksel Kentsel Konut, and Dokusunun Yeniden Kazanımı. Gazi Üniversitesi Şehir ve Bölge Planlama Bölümü (Yazar), Şehircilik Çalışmaları, Nobel Yayın Dağıtım.(S. 385.). Ankara.

Hang, J., Sandberg, M., Li, Y., \& Claesson, L. (2009). Pollutant dispersion in idealized city models with different urban morphologies. Atmospheric Environment, 43(38), 6011-6025. https://doi.org/10.1016/j.atmosenv.2009.08.029.

He, L., Hang, J., Wang, X., Lin, B., Li, X., \& Lan, G. (2017). Numerical investigations of flow and passive pollutant exposure in high-rise deep street canyons with various street aspect ratios and viaduct settings. Science of the Total Environment, 584, 189-206.

Hunter, L. J., \& Wales, N. S. (1992). An investigation of three-dimensi onal characteristics of flow regimes within the urban canyon. Atmospheric Environment. Part B. Urban Atmosphere, 26(4), 425-432.

Janhäll, S. (2015). Review on urban vegetation and particle air pollution Deposition and dispersion. Atmospheric Environment, 105, 130-137. https://doi.org/10.1016/j.atmosenv.2015.01.052.

Jeanjean, A. P. R., Monks, P. S., \& Leigh, R. J. (2016). Modelling the effectiveness of urban trees and grass on PM2.5reduction via dispersion and deposition at a city scale. Atmospheric Environment, 147, 1-10. https:// doi.org/10.1016/j.atmosenv.2016.09.033.

Ketterer, C., \& Matzarakis, A. (2016). Mapping the Physiologically Equivalent Temperature in urban areas using artificial neural network. Landscape and Urban Planning, 150, 1-9. https://doi.org/10.1016/j.landurbplan.2016.02.010.

Klein, P., Leitl, B., \& Schatzmann, M. (2007). Driving physical mechanisms of flow and dispersion in urban canopies. International Journal of Climatology. A Journal of the Royal Meteorological Society, 27(14), 1887-1907.

Klemm, K., Heim, D., (2009). Local Wind and Rain Conditions in Semi-Closed Narrow Corridors Between Buildings. Eleventh International IBPSA Conference, July 27-30, Glasgow, Scotland.

Kopar, İ., Zengin,M.(2009).Coğrafi faktörlere bağlı olarak erzurum kentinde hava kalitesinin zamansal ve mekânsal değişiminin belirlenmesi.Türk Coğrafya Dergisi, 53, 51-58.

Koşan, Z., Kavuncuoğlu, D, Çalıkoğlu, E., Bilge Yerli, E. (2018). Evaluation of air pollution by $\mathrm{PM}_{10}$ and $\mathrm{SO}_{2}$ levels in Erzurum province, Turkey: Descriptive study. Journal of Surgery and Medicine, 2 (3), 265-268. DOI: $10.28982 /$ josam. 422921 .

Lee, H., Mayer, H., \& Kuttler, W. (2020). Impact of the spacing between tree crowns on the mitigation of daytime heat stress for pedestrians inside EW urban street canyons under Central European conditions. Urban Forestry \& Urban Greening, 48, 126558.

Li, C., Wang, Z., Li, B., Peng, Z.-R., \& Fu, Q. (2019). Investigating the relationship between air pollution variation and urban form. Building and Environment, 147, 559-568, https://doi.org/10.1016/j.buildenv.2018.06.038.

Li, G., Ren, Z., \& Zhan, C. (2020). Sky View Factor-based correlation of landscape morphology and the thermal environment of street canyons: A case study of Harbin, China. Building and Environment, 169, 106587.

Lu, C., \& Liu, Y. (2016). Effects of China's urban form on urban air quality. Urban Studies, 53(12), 2607-2623. https://doi.org/10.1177/ 0042098015594080 .

Matzarakis, A., Matuschek, O. (2011). Sky View Factor as a parameter in applied climatology-Rapid estimation by the Sky Helios Model. Meteo- 
rologische Zeitschrift, 20(1), 39-45.

Ma X, Wang M, Zhao J, Zhang L, Liu W (2020). Performance of different urban design parameters in improving outdoor thermal comfort and health in a pedestrianized zone. Int J Environ Res Public Health, 17(2258), 2-19. https://doi.org/10.3390/ijerph17072258.

MGM, (2018) Turkish State Meteorological Service (MGM). https://www. mgm.gov.tr/. Data of Ministry of Agriculture and Forestry, General Directorate of Meteorology, Ankara.

Mutlu, E., Yilmaz S., Yilmaz H., Mutlu B.E. (2018). Analysis of urban settlement unit by ENVI-met according to different aspects in cold regions. $6^{\text {th }}$ annual international Conference on Architecture and Civil Engineering (ACE 2018), oral presentation, 14-15 May 2018, Singapore.

Neofytou, P., Venetsanos, A. G., Rafailidis, S., \& Bartzis, J. G. (2006). Numerical investigation of the pollution dispersion in an urban street canyon. Environmental Modelling and Software, 21(4), 525-531. https://doi. org/10.1016/j.envsoft.2004.08.012.

Nosek, Š., Fuka, V., Kukačka, L., Kluková, Z., \& Jaňour, Z. (2018). Streetcanyon pollution with respect to urban-array complexity: The role of lateral and mean pollution fluxes. Building and Environment, 138, 221-234.

Oke, T. R. (1988). Street design and urban canopy layer climate. Energy and Buildings, 11(1-3), 103-113.

Öztürk, MZ, Çetinkaya G, Aydın S. (2017) Köppen-Geiger iklim sınıflandırmasına göre Türkiyénin iklim tipleri. Coğrafya Dergisi, 35,17-27.

Pugh, T. A. M., MacKenzie, A. R., Whyatt, J. D., \& Hewitt, C. N. (2012). Effectiveness of green infrastructure for improvement of air quality in urban street canyons. Environmental Science \& Technology, 46(14), 7692-7699.

Partigöç, N. S., \& Çubukçu, K. M. (2017). Hava kirliliği ve kent ilişkisine ampirik bakış: ekolojik sürdürülebilirlik ekseninde bir değerlendirme. Akademia Disiplinlerarası Bilimsel Araştırmalar Dergisi, 3(2), 28-45.

Qaid A, Ossen DR (2015). Effect of asymmetrical street aspect ratios on microclimates in hot, humid regions. International Journal Biometeorology, 59(6), 657-677.

Qaid, A., Lamit, H. Bin, Ossen, D. R., \& Rasidi, M. H. (2017). Effect of the position of the visible sky in determining the sky view factor on micrometeorological and human thermal comfort conditions in urban street canyons. Theoretical and Applied Climatology. https://doi.org/10.1007/ s00704-016-2023.

Salim, S. M., Buccolieri, R., Chan, A., Di Sabatino, S., \& Cheaha, S. C. (2011). Large Eddy Simulation of the aerodynamic effects of trees on pollutant concentrations in street canyons. Procedia Environmental Sciences, 4(19), 17-24.

Salim, Salim Mohamed, Buccolieri, R., Chan, A., \& Di Sabatino, S. (2011). Numerical simulation of atmospheric pollutant dispersion in an urban street canyon: Comparison between RANS and LES. Journal of Wind Engineering and Industrial Aerodynamics, 99(2-3), 103-113. https:// doi.org/10.1016/j.jweia.2010.12.002.

Sarı E.N., Hava Kirliliği ve Konut Dokusu Arasındaki İlişkinin Analizi: Erzurum Örneği, Atatürk Üniversitesi Fen Bilimleri Enstitüsü, Yüksek Lisans Tezi

Sar1 E.N., Yilmaz S., (2019). Spatial comparison of air pollution over urban pattern. $9^{\text {th }}$ International Symposium on Atmospheric Sciences, ITU, ATMOS2019, Oral presentation, October 23-26, 2019, Istanbul/Turkey.

Sar1 E. N., Y1lmaz S., Y1lmaz B. G. 2020. Definition of pedestrian friendly street parameters and evaluation in the case of Erzurum city Pedestrians, Maurizio Tira,Michèle Pezzagno,Anna Richiedei, (Ed.), Urban Spaces and Health - Proceedings of the XXIV International Conference on Living and Walking in Cities (LWC, September 12-13, 2019, Brescia, Italy), Taylor eBookstore, (s. 55-61). London.

Schatzmann, M., Leitl, B., \& Liedtke, J. (2000). Dispersion in urban environments; comparison of field measurements with wind tunnel results. Environmental Monitoring and Assessment, 65(1), 249-257. https://doi. org/10.1023/A:1006493319734.
Schindler, M., \& Caruso, G. (2014). Urban compactness and the trade-off between air pollution emission and exposure: Lessons from a spatially explicit theoretical model. Computers. Environment and Urban Systems, $45,13-23$.

Shashua-Bar, L., \& Hoffman, M. E. (2000). Vegetation as a climatic component in the design of an urban street: An empirical model for predicting the cooling effect of urban green areas with trees. Energy and Buildings, 31(3), 221-235.

Shi Y, Xie X, Fung JCH, Ng E (2018). Identifying critical building morphological design factors of street-level air pollution dispersion in high-density built environment using mobile monitoring. Building and Environment, 128, 48-259. https://doi.org/10.1016/j.buildenv.2017.11.043.

Shishegar N (2013). Street Design and Urban Microclimate: Analyzing the Effects of Street Geometry and Orientation on Airflow and Solar Access in Urban Canyons", Journal of Clean Energy Technologies 1(1), 52-56. https://doi.org/10.7763/JOCET.2013.V1.13.

Taseiko, O. V., Mikhailuta, S. V., Pitt, A., Lezhenin, A. A., \& Zakharov, Y. V. (2009). Air pollution dispersion within urban street canyons. Atmospheric Environment, 43(2), 245-252. https://doi.org/10.1016/j.atmosenv.2008.09.076.

Theurer, W. (1999). Typical building arrangements for urban air pollution modelling. Atmospheric Environment, 33(24-25), 4057-4066.

UN., (2018). World Population Prospects 2017, United Nations DESA / Population. Divisionhttps://www.un.org/development/desa/en/news/ population/2018-revision-of-world-urbanization-prospects.html

Vos, P. E. J., Maiheu, B., Vankerkom, J., \& Janssen, S. (2013). Improving local air quality in cities: To tree or not to tree? Environmental Pollution, 183, 113-122. https://doi.org/10.1016/j.envpol.2012.10.021.

Wania, A., Bruse, M., Blond, N., \& Weber, C. (2012). Analysing the influence of different street vegetation on traffic-induced particle dispersion using microscale simulations. Journal of Environmental Management, 94(1), 91-101.

WHO, (2005). World Health Organization, Air Quality Guidelines-global update 2005. WHO.https://apps.who.int/iris/bitstream/handle/10665/69477/WHO_SDE_PHE_OEH_06.02_eng.pdf;jsessionid $=$ EDEDC23411D0DD29BE3D45DC26D3FCDC? sequence $=1$.

Yavaş, M, Yilmaz S (2020). İklim duyarlı kentsel tasarım ilkeleri: Erzurum kenti örneği. Journal of Planning, 30(2), 294-312. https://doi. org/10.14744/planlama.2020.04934.

Yllmaz, S., Sezen, I. (2004). Erzurum Kentinde Hava Kirliliğine Karşı1 Halkın Duyarlılığının Belirlenmesi, Akdeniz Üniversitesi Ziraat Fakültesi Dergisi, 17(2), 199- 206

Yilmaz, S., Mutlu, E., Yilmaz, H. (2018). Quantification of thermal comfort based on different street orientation in winter months of urban City Dadaşkent. Acta Horticulturae, 1215: 67-72. Doi: 10.17660/Actahortic.2018.

Yilmaz S, Mutlu BE, Aksu A, Mutlu E, Qaid A (2020) Street design scenarios using vegetation for sustainable thermal comfort in Erzurum, Turkey. Environmental Science and Pollution Research, https://doi.org/10.1007/ s11356-020-10555-z,inpress.

Yuan, C., Ng E.,Norford, L.K. (2014). Improving air quality in high-density cities by understanding the relationship between air pollutant dispersion and urban morphologies. Building and Environment, 71, 245-258.

Zhang, H., Xu, T., Zong, Y., Tang, H., Liu, X., \& Wang, Y. (2015). Influence of meteorological conditions on pollutant dispersion in street canyon. Procedia Engineering, 121, 899-905. https://doi.org/10.1016/j.proeng.2015.09.047.

Zhou, B., Lauwaet, D., Hooyberghs, H., De Ridder, K., Kropp, J. P., \& Rybski, D. (2016). Assessing seasonality in the surface urban heat island of London. Journal of Applied Meteorology and Climatology, 55 (3),493-505.

URL- I ÇŞB, (2018). https://www.havaizleme.gov.tr, Çevre ve Şehircilik Bakanlığı, Ankara. 